\title{
Reported Lead Levels in Different Environmental Matrices in Colombia*
}

\section{Niveles de plomo reportados en diferentes matrices ambientales en Colombia}

Received: May 27, 2019. | Accepted: July 3, 2020 | Published: June 22, 2021

Carol-Brigitte Hernández-Rodríguez

Universidad Distrital Francisco José de Caldas, Colombia

ORCID: 0000-0003-2731-4643

Alvaro-Martín Gutiérrez-Malaxechebarría a

Universidad Distrital Francisco José de Caldas, Colombia

ORCID: 0000-0002-2306-1610

Carlos-Alfonso Zafra-Mejía

Universidad Distrital Francisco José de Caldas, Colombia

ORCID: 0000-0002-4061-4897

${ }^{*}$ Research article

${ }^{a}$ Corresponding author. E-mail: amgutierrezm@udistrital.edu.co

DOI: https://doi.org/10.11144/Javeriana.iued25.rlld

How to cite this article:

C. B. Hernández-Rodríguez, A. M. Gutiérrez-Malaxechebarría, and C. A. Zafra-Mejía, "Lead levels in Colombia reported in different environmental matrices," Ing. Univ., vol. 25, 2021 [0nline]. https://doi.org/10.11144/Javeriana.ived25.rlld 


\section{Abstract}

Objective: The aim of this paper is to present a review of specific cases that reported lead concentrations in blood, objects, food, soil, bioindicators, air, and water in specific places in Colombia and evaluate the reported concentrations against target values. Materials and Methods: A systematic qualitative literature review of publications between 1995 and 2019 was done; using Boolean operators 1571 papers were identified, to which 3 inclusion and 4 exclusion criteria were applied. A total of 57 studies met the defined criteria. The reports in these studies were geolocalized and compared with acceptable values. Results and Discussion: Results suggest that lead is present in all environmental matrices, widely distributed in the Colombian territory, and that $72 \%$ of the cases exceeded regulation limits. The percentage of noncompliance per environmental matrix was $89 \%$ for blood samples, $71 \%$ in food, $63 \%$, in soil, $89 \%$ for bioindicators, $60 \%$ for air, and $55 \%$ for water. Conclusion: These results show that lead pollution is a large-scale problem in the country, more systematic studies are needed, and control measures, policy-making and regulatory updating should be pursued.

Keywords: Lead (II), Colombia, poisoning, environmental pollution, heavy metals, systematic review.

\section{Resumen}

Objetivo: este artículo tiene como propósito presentar una revisión de casos concretos que reporten concentraciones de plomo en sangre, objetos, alimentos, suelos, bioindicadores, aire y agua en lugares específicos del territorio colombiano y evaluar las concentraciones reportadas con valores objetivo. Materiales y Métodos: se realizó una revisión sistemática cualitativa de literatura entre los años 1995 y 2019, empleando operadores booleanos que permitieron identificar 1571 artículos, sobre los que se aplicaron 3 criterios de inclusión y 4 criterios de exclusión. 57 estudios cumplieron con los criterios definidos. Los reportes fueron ubicados geográficamente y comparados con los valores permisibles. Resultados y discusión: los resultados evidencian que el plomo está presente en todas las matrices ambientales, que está ampliamente distribuido en el territorio colombiano y que el $72 \%$ del total de los casos sobrepasan los límites establecidos por la normatividad para cada matriz. Este porcentaje de incumplimiento por matriz ambiental fue de $89 \%$ en el caso de muestras de sangre, $71 \%$ en alimentos, $63 \%$, en suelos, $89 \%$ en bioindicadores, $60 \%$ en aire y $55 \%$ para el agua. Conclusiones: estos resultados evidencian que la contaminación por plomo es un problema a gran escala en el país, que se requieren más estudios sistemáticos y que se deberían extremar las medidas de control, definir políticas y actualizar la normatividad.

Palabras clave: Plomo (II), Colombia, intoxicación, contaminación, metales pesados, revisión sistemática. 


\section{Introduction}

Heavy metals are defined as those that form positive ions in a solution and have a density five times greater than that of water. In addition, they have a particular toxicological importance as in the case of lead, cadmium, and mercury [1]. Lead is widely used for its importance in modern industry [2] due to properties such as a low melting point $\left(327.4{ }^{\circ} \mathrm{C}\right)$, high density, low hardness, resistance to acid and chemical stability in air, water, and soil. For these reasons it is appealing for use in industries related to construction, paint manufacturing, electroplating, mining, metallurgy, manufacturing and recycling of electric accumulators and batteries, among others [3]. It is for this reason that among the main sources of exposure to this metal are lead paints used inside and outside of buildings [4], [5], atmospheric emissions from stationary sources such as paint factories, metal processing facilities, battery factories, power plants, hazardous waste treatment plants, and mobile sources [6]; also, contaminated food and water, ceramics with leaded glazes [7], and occupational sources.

Lead is transported through all environmental matrices. Initially it can be emitted into the air, where, by the action of rain, it precipitates and directs toward bodies of water [8]. On the other hand, the soil appears as a natural deposit of this heavy metal, where part of it remains indefinitely [9] and the rest is transported to bodies of water through runoff, either in rural areas or on the paved streets in urban areas [10]. Additionally, lead is transferred to plant or animal species in contact with contaminated air, soil, or water, accumulating and moving up the food chain until it reaches humans. It can also reach humans through contact of food with welds that contain lead, as in the case of cans [11] or utensils [4], or even through inhalation or dermal contact with projectiles [12].

Once in the human body, this metal has no known biological function, is highly persistent, bioaccumulates in organs and tissues [13], [14], increases the risk of lung, stomach, or bladder cancer [15], [16], and generates damage to the nervous, reproductive, cardiovascular, gastrointestinal, hematopoietic, and immune systems [17], [18].

In Colombia, despite the fact that lead was eliminated from gasoline through the Decree 948 of 1995 [19], resolution 1180 of 2006 establishes a maximum allowed of $0.013 \mathrm{~g} / \mathrm{L}$ [18]. Therefore, its release into the atmosphere continues being a public health problem [20]. However, in the country no study has been carried out that makes a systematic review of its concentrations in the environment or in clinical studies, underestimating the real magnitude of this problem and generating a large gap in knowledge about the associated toxicological risks in the country. In addition, the lead content is not currently regulated in some of the environmental matrices, such as soil and living beings. 
The main purpose of this document is to contribute to the review of specific cases that report lead concentrations in human blood, objects, food, soil, bioindicators, air, and water in clearly defined places as detailed in articles published between 1995 and 2019. The search was carried out in Scopus and SciELO. The concentrations identified were geolocated and compared with national and international regulations. It was found that, in most cases, lead concentrations exceed established limits and are also present in a wide regional diversity across the country and in all defined environmental matrices, which should lead to extreme control measures, definition of policies, and updating of regulations.

\section{Materials and Methods}

A qualitative systematic review [21] of the scientific articles published in databases on the presence of lead in the different environmental matrices in Colombia was carried out, using Boolean operators such as "AND" and "OR" to obtain more specific results [22]. In the first case, an advanced search was carried out in the Scopus database requesting articles with the expressions ("lead" OR "lead" OR "Pb") in their title, abstract, or keywords and that in turn contained throughout the document the words "Colombia AND metal." Additionally, another advanced search was carried out, this time in the regional information source SciELO, with the expression (((Lead) OR (lead) OR (Pb)) AND (Colombia)) [23]. However, the results covered articles that were not relevant to the objective of our research, although they included the words "lead" and "Colombia" in their content, which is why it was required to verify them under inclusion and exclusion criteria [24], [25], as seen in figure 1.

Three inclusion criteria were defined as follows: 1) the studies were carried out in the period between 1995 and 2019 were included, that is, starting from the year in which regulations eliminated lead in gasoline [19]; 2) the samples of the environmental matrix under investigation were located in Colombia, since some authors mentioned the country, but used samples from other places and therefore their results were not of interest for this study; and 3 ) the results reported quantitatively the lead concentrations determined, in such a way that they could be compared with reference values.

Similarly, 4 exclusion criteria were defined as follows: 1) studies found in both searches (duplicates); 2) studies that reported lead levels which were not determined by the study itself, that is, those that reported secondary information; 3) studies that did not report the specific place where the samples were taken, which ruled out the possibility of geolocating and performing an analysis based on said location; and 4) studies carried out under controlled or laboratory conditions, that is, studies that did not show actual field results, since it is essential that the appearance of lead in the sample occurred involuntarily. 
Finally, results were coded according to the environmental matrix in which they were reported: Water (W), air (A), soil (S), bioindicators (V), blood in humans (B), food (F), and objects $(\mathrm{O})$. The concentrations of lead reported were compared with the maximum limits allowed by national and international regulations and the associated sources and effects observed were identified. Additionally, results were georeferenced and located on a map of the country.

\section{Figure 1. Methodological scheme of the systematic search}

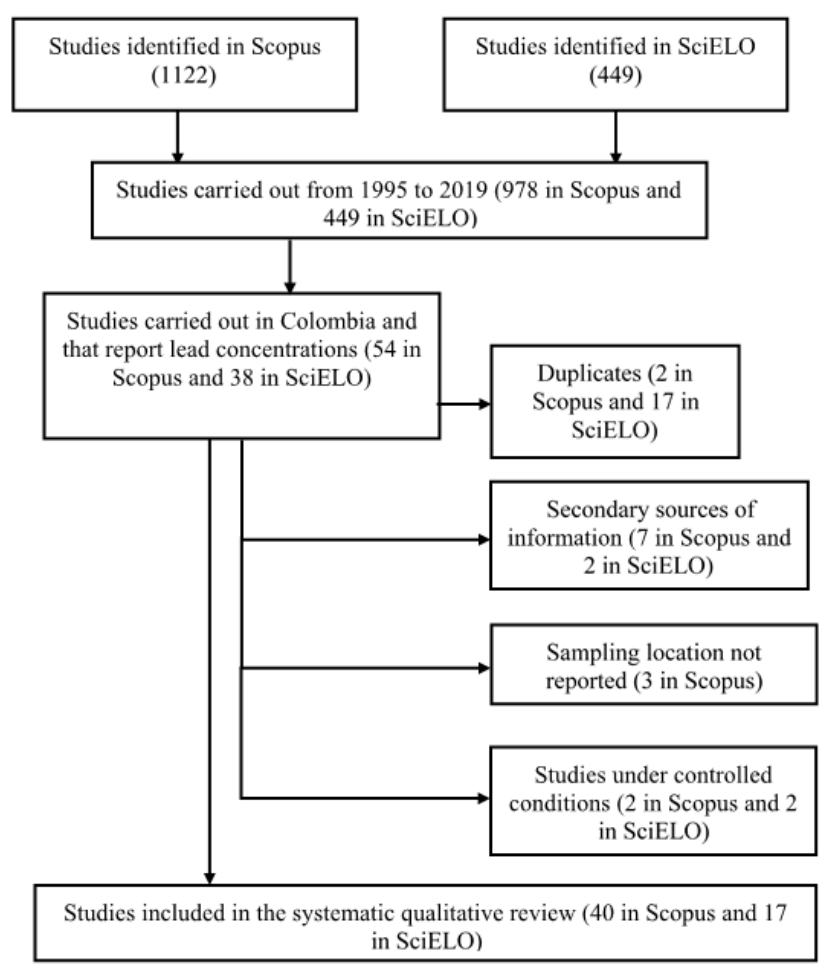

\section{Source: Adapted from "Preferred Reporting Items for Systematic Reviews and Meta-Analyzes: The PRISMA Statement," 2009 [26].}

\section{Results}

Figures 2 and 3 show the results of the systematic search in the databases used. As indicated in figure 1, 1122 articles were found in Scopus and 449 in SciELO, that is, a total of 1571 articles adding up the results from the two databases. This number reduced to 54 and 38 once the inclusion criteria had been validated and successively to 40 and 17 , respectively, after verification of the exclusion criteria, for a total of 57 articles. Of these, 9 determined the lead level in blood in populations of children and adults (15\%), 1 in objects (2\%), 14 in food $(23 \%), 8$ in soil (13\%), 9 in bioindicators (17\%), 5 in air $(9 \%)$, and 11 in water $(21 \%)$, as presented in figure 3 . 
Figure 2. Preliminary results of the database search

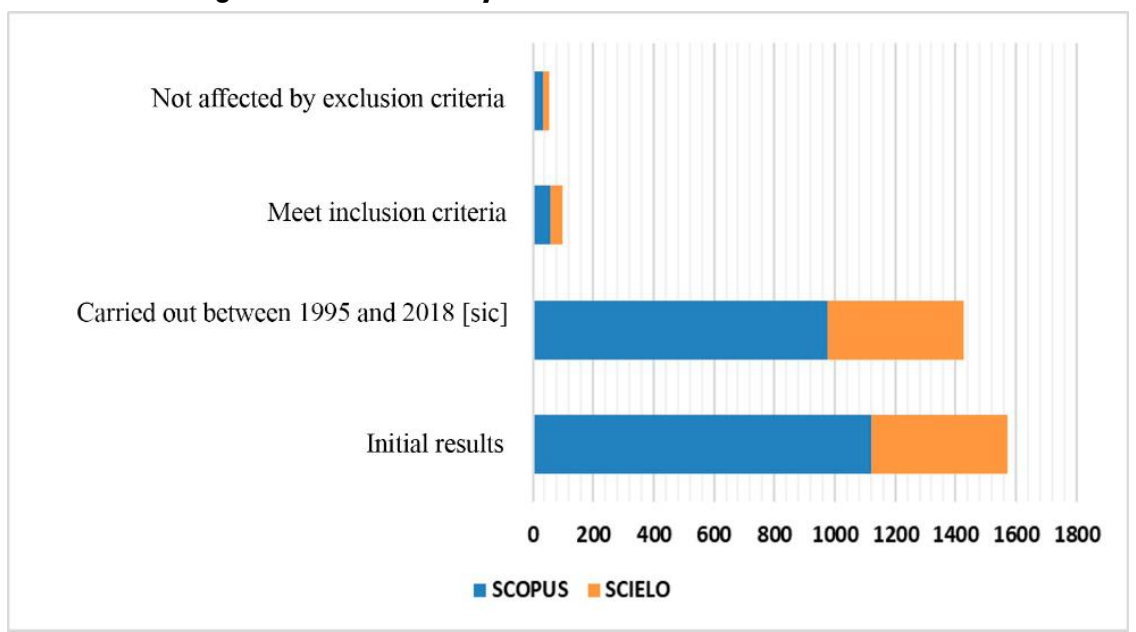

Source: Own source.

Figure 3. Articles validated by environmental matrix

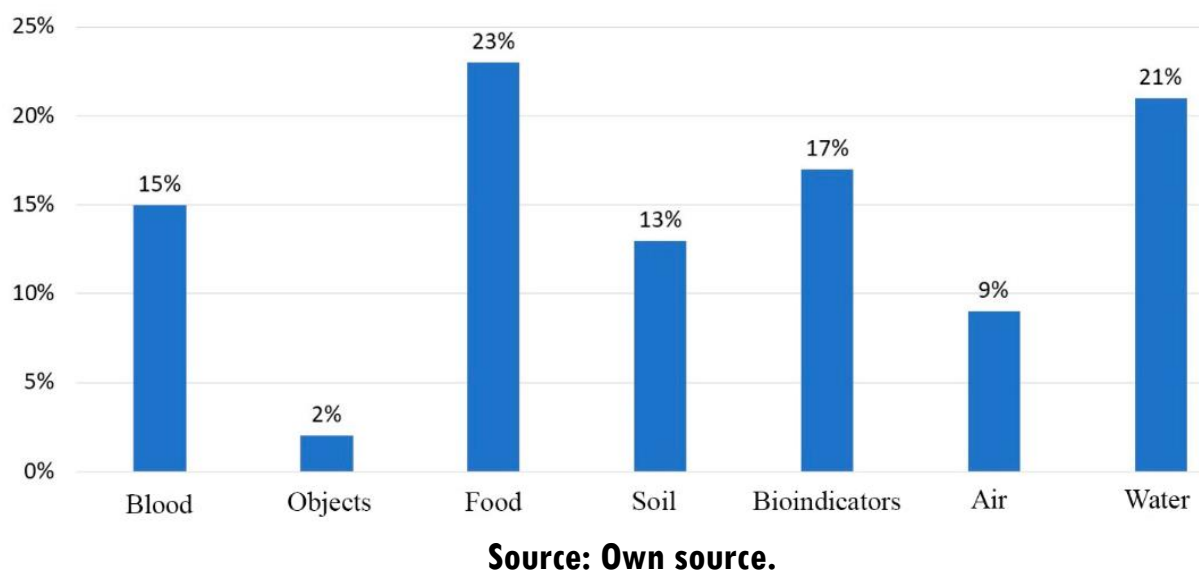

Table 1 shows the main characteristics of the studies resulting from the systematic review, while figure 5 geolocates the studies that reported lead levels in the different environmental matrices. It can be observed that they are distributed mainly in the Caribbean Coast region and the central area of the country. The city of Bogotá stands out as the one with the highest frequency, followed by Cartagena, Cali and Medellín.

Lead concentrations in blood were compared to maximum acceptable limits determined by the Center for Disease Control and Prevention (CDC), which states that health effects can occur with blood lead levels as low as $5 \mu \mathrm{g} / \mathrm{dL}$, while in adults the maximum allowed value is $38 \mu \mathrm{g} / \mathrm{dL}[27]$. 


\section{Blood Lead Levels}

Regarding the studies carried out in the country, it was found that the first was an occupational study and was carried out in Bogotá [28]. In the battery production industry, $84 \%$ of the workers had lead levels greater than $38 \mu \mathrm{g} / \mathrm{dL}$ associated with variables such as infrequent change of clothes, washing clothes at home and poor hygiene and industrial safety habits. Similarly, it was reported the presence of symptoms such as abdominal pain, headache, blurred vision, metallic taste in the mouth, cramps, and irritation in the eyes and throat. This is due to the fact that in the battery industry lead is used in the casting of grids, edges, and solder, turning into a source of exposure to lead vapors and particles. This situation worsens in informal establishments where there is no environmental control measures (ventilation) and occupational health (personal protection elements). Other studies carried out in Bogotá also show high levels of lead in other industrial sectors. Blood lead levels of $39 \mu \mathrm{g} / \mathrm{dL}$ were found in a printing press [29] and higher than $77 \mu \mathrm{g} / \mathrm{dL}$ in other battery manufacturing companies, reporting, among others, symptoms such as headaches, abdominal pain, anemia, basophilic stippling, metallic taste, blurred vision, and memory impairment [30].

On the other hand, in 2007, the first clinical study was carried out in children aged 5 to 9 in Cartagena, in which it was found that $7.41 \%$ of the sample presented levels greater than 10 $\mu \mathrm{g} / \mathrm{dL}$. Results were associated with the fact that metal smelting and fishing lead weight manufacturing activities were carried out in the study sites, mostly informally in homes or warehouses, thus workers indirectly exposed their children [31]. Another study, carried out on 32 children under 12 years of age, para-occupationally exposed to the battery recycling process in the municipality of Soacha and in the city of Bogotá, found that they all presented lead levels higher than those allowed, with a maximum value of $90 \mu \mathrm{g} / \mathrm{dL}$ and symptoms such as headaches, abdominal pain, hyporexia, Burton's line, vomiting, and sleep disorder [20].

In recent years, investigations have focused on environmental exposure to lead, beginning with one carried out on 350 children aged 6 to 14 in the north of the city of Cali [32], in which 69 minors exposed to industrial emissions from battery and metal smelting factories, as well as 16 unexposed minors, presented levels greater than $5 \mu \mathrm{g} / \mathrm{d}$, which are those allowed by regulations [33]. The latter were associated with the handling of batteries at home, the consumption of contaminated fish, and a low socioeconomic level. Similarly, in the city of Cartagena, 118 blood samples were collected from children aged 5 to 16 , of which $3.4 \%$ (4 samples) had levels above the acceptable value, with a maximum of $34.05 \mu \mathrm{g} / \mathrm{dL}$ in the El Bosque neighborhood, associated with exposure to emissions from companies engaged in metal smelting [34]. Another study [35] that reviewed data in several Caribbean cities found values within regulations for Cartagena, Valledupar, and La Paz, but in Tasajera values of 
8.9 to $34.05 \mu \mathrm{g} / \mathrm{dL}$ were reported. This relationship between exposure to emissions in industrial zones and blood lead levels is also observed in a study carried out in the city of Bogotá, which reported a maximum value of $67.91 \mu \mathrm{g} / \mathrm{dL}$ and averages above $10 \mu \mathrm{g} / \mathrm{dL}$ in the localities (districts) of Puente Aranda, Rafael Uribe Uribe, Kennedy, Antonio Nariño, San Cristóbal, and Usme, most of which have been declared as source areas of air pollution [36], with accounts of clinical manifestations such as memory loss, tremors, and attention problems [37].

Regarding the adult population, in the city of Cali, lead levels associated with a poor diet and low socioeconomic status were reported in 14 women in their first trimester of pregnancy, with values above $5 \mu \mathrm{g} / \mathrm{dL}$, which persisted until the third trimester in 7 of them [38]. On the other hand, in the municipalities of San Marcos and Sucre in the region of La Mojana (Sucre), lead levels of $0.15 \mu \mathrm{g} / \mathrm{dL}$ to $52.46 \mu \mathrm{g} / \mathrm{dL}$ were identified as a consequence of the use in the area of agrochemicals such as lead arsenate and the use of food and water from the Cauca River, in which substances derived from gold mining and industrial activity are transported along its streambed [39]. On the other hand, J. Gerstner Garcés [12] explored lead poisoning from projectiles or shrapnel lodged in the human body as a consequence of gunshot wounds, presenting two cases in the city of Cali with lead levels of 62 and $90.3 \mu \mathrm{g} / \mathrm{dL}$ in blood, associated with symptoms in the gastrointestinal, nervous, musculoskeletal, and circulatory systems.

\section{Lead Levels in Objects}

Currently, Colombia has technical regulations on the health requirements for toys, their components and accessories that are marketed in the national territory, issued by resolution 3388 of 2008 [40]. This regulation establishes a maximum value of $0.7 \mu \mathrm{g}$ for the daily bioavailability of lead resulting from the use of a toy and $90 \mathrm{mg} / \mathrm{kg}(\mathrm{ppm})$ as the maximum migration of this metal to the human body by ingestion. However, a study identified 8 samples of paints used to coat toys with a lead level higher than recommended, with values ranging from 244 to 47,600 ppm, of which 6 toys were manufactured in Colombia and the others in China [41]. In the same way, it was found that $64 \%$ of the analyzed household paints contain a total concentration of lead greater than 600 parts per million (ppm) [42], when the standard establishes that a concentration of $100 \mathrm{ppm}$ should not be exceeded [43]. This presents a significant risk to the health of children since paint particles can be ingested directly or indirectly when they are mix with dust or remain on the hands. At the international level, lead has also been found in different objects associated with children such as toys, stained glass, arts and crafts materials, and faux jewelry and cosmetics [7]. 


\section{Contaminated food}

Worldwide, the Codex Alimentarius [44] establishes the maximum limits for contaminants in different foods and their provisional tolerable monthly intake, which for lead is $25 \mu \mathrm{g} / \mathrm{kg}$ of body weight. In Colombia, the maximum levels of lead have been established in food and fishery products for human consumption [45], [46].

The consumption of food contaminated with lead directly affects the health of human beings, even in low amounts, since if the exposure is constant it can increase the risk of poisoning. Such is the case of foods for daily consumption such as potatoes, from Tunja, Boyacá, in which Mariño and others [47] identified lead with values ranging between 0.085 and 0.150 $\mathrm{mg} / \mathrm{kg}$. Also, chives, lettuce, and cabbage grown in Norte de Santander [48] that exceeded the maximum limit established by the Ministry of Health were identified. Likewise, in the east of the city of Cali, lead levels in drinking water between $0.11-0.36 \mu \mathrm{g} / \mathrm{L}$ [49] were reported. Although these values are below the limit of $10 \mu \mathrm{g} / \mathrm{L}$ established in Colombian regulations [50], they constitute a chronic health risk since daily consumption cannot be reduced. The same applies to the consumption of salt that, although it can be reduced, it is a product of daily consumption and thus it is worrying that lead levels of up to $1 \mathrm{mg} / \mathrm{kg}$ have been reported in table salt distributed by different supermarkets in Bogotá [51].

Regarding bovine meat, those from the valleys of the Sinú and San Jorge rivers, in the department of Córdoba, reported lead concentrations of $0.007-0.095 \mu \mathrm{g} / \mathrm{g}$ in muscle and 0.020-0.098 $\mu \mathrm{g} / \mathrm{g}$ in liver tissue [52]; although these levels do not exceed the $0.1 \mathrm{ppm}$ limit, the upper end values are very close to it. In the city of Barrancabermeja, levels above the limits established for bovine meat and viscera were reported, with average values of 0.62 , 0.54 and $0.24 \mathrm{mg} / \mathrm{kg}$ in liver, kidney, and muscle tissues, respectively, which were found to be higher than those found in the municipality of Yondó, with values of $0.49,0.38$, and 0.22 $\mathrm{mg} / \mathrm{kg}$. The source of the metal is associated with the contamination of the pastures consumed by the cattle as a consequence of the industrial activity carried out in neighboring areas [53], which can generate acute health effects in livestock [54]. This is confirmed by a study that made an inventory of the pastures near an oil refinery in Barrancabermeja, Santander, and to extraction wells in Yondó, Antioquia, showing higher concentrations of lead at a distance of $100 \mathrm{~m}$ from the oil refinery, both in soil and in plant species, with values of 794.04 and 16.07 $\mathrm{mg} / \mathrm{kg}$, respectively [55].

Different studies have been carried out in order to determine the $\mathrm{Pb}$ content in frequently consumed fish. Eremophilus mutisii ("Capitán de la Sabana" or Captain of the Savanah) was analyzed in the municipalities of Chocontá and Suesca, detecting maximum concentrations of 7.7 and $7.3 \mathrm{ppm}$ respectively, which exceeds alarmingly the limit of $0.3 \mathrm{ppm}$ [56]. However, in the Ciénaga de Mallorquín, in the city of Barranquilla, lead levels of 0.66-2.03 
$\mu \mathrm{g} / \mathrm{g}$ (dry weight) were reported, associated with the Barranquilla industrial area, as well as the accumulation of pollutants in mangrove forests and in the sediment load of the Magdalena River [57]. Similarly, in the upper basin of the Chicamocha River, lead levels were found in the Nile tilapia (Oreochromis niloticus), with maximum values of $0.47 \mu \mathrm{g} / \mathrm{g}, 0.51 \mu \mathrm{g} / \mathrm{g}$, and $0.45 \mu \mathrm{g} / \mathrm{g}$ in liver, gill, and muscle tissue respectively [58]. Additionally, in the Gulf of Urabá, amounts of $\mathrm{Pb}$ were reported in crevalle jack (Caranx hippos) above the allowed limit in a range of $0.667-23.378 \mathrm{mg} / \mathrm{kg}$, with mean values of $1.30 \mathrm{mg} / \mathrm{kg}$ in muscle tissue, $0.95 \mathrm{mg} / \mathrm{kg}$ in residues, $7.8 \mathrm{mg} / \mathrm{kg}$ in viscera, $13.3 \mathrm{mg} / \mathrm{kg}$ in head and gills, and $19.4 \mathrm{mg} / \mathrm{kg}$ in fins and tail [59]. On the other hand, levels below the reference value were found in fish marketed in the city of Bogotá, with average maximum concentrations of $0.0595 \mathrm{mg} / \mathrm{kg}$ for salmon (Oncorhynchus sp.), followed by the sierra (Scomberomorus sp.) with $0.034 \mathrm{mg} / \mathrm{kg}$, snook (Centropomus sp.) with $0.0289 \mathrm{mg} / \mathrm{kg}$, Basa fish (Pangasius sp.) with $0.029 \mathrm{mg} / \mathrm{kg}$, red tilapia (Oreochromis sp.) with $0.0281 \mathrm{mg} / \mathrm{kg}$, catfish (Pseudoplatystoma sp.) with 0.0264 $\mathrm{mg} / \mathrm{kg}$, "bocachico" (Prochilodus sp.) with $0.0254 \mathrm{mg} / \mathrm{kg}$ and long-whiskered catfish (Pimelodus sp.) with $0.0199 \mathrm{mg} / \mathrm{kg}$ [60].

Also, lead contents greater than that allowed by international regulations $(0.1-0.3 \mathrm{mg} / \mathrm{L})$ has been detected in artisanal alcoholic beverages such as "ñeque" or "chirrinchi" [61]. For these cases, in the department of Bolívar they found levels between 0.5 and $0.76 \mathrm{mg} / \mathrm{L}$ [62]; however, these values were higher than those found in a second study in the department of Sucre, with a maximum of $0.41 \mathrm{mg} / \mathrm{L}$ [63]. In the latter, the San Jorge river was determined as a possible source of contamination since the water with which the drinks were prepared was taken from its waters and its contamination by mining activity has been reported.

Contamination with $\mathrm{Pb}$ in fish is attributed to eating habits that include sediments [56], benthic algae, phytoplankton, eggs and larvae of other species, as well as the presence of the metal in the aquatic ecosystem as a result of the discharge of domestic and industrial wastewater [58], [57]. This increases the bioavailable lead for animal and plant species in water systems, which eventually bioaccumulates it in their body. Such is the case of fish species such as Eremophilus mutisii ("Capitán de la Sabana" or Captain of the Savanah), striped catfish (Pseudoplatystoma orinocoense and P. metaense) and capaz (Pimelodus grosskopfii) from the Bogotá river (Cundinamarca), Puerto López (Meta) and the Betania dam (Huila, Colombia), respectively [64]. As a result, the presence of lead in blood was identified (in $93 \%$ of captains, $44 \%$ of striped catfish, and $28 \%$ of capaz) with levels between 3.6 and $9.5 \mu \mathrm{g} / \mathrm{dL}$.

On the other hand, contaminated crops can indicate an exchange of these elements with the soil, deposition of atmospheric emissions, residues of lead ammunition, application of fertilizers, pesticides and soil conditioners [65]. Exposure to this type of pollutants is aggravated for people of low socioeconomic status due to factors such as proximity to or poor handling of hazardous waste, emissions from nearby atmospheric sources, inhalation of 
particulate material from unpaved or poorly maintained roads, restricted access to drinking water, and overcrowding [6].

\section{Bioindicators of Contamination}

In this case, exposure to lead associated with the ingestion of food contaminated by contact with solid waste with concentrations between 2.86 and $9624 \mathrm{mg} / \mathrm{kg}$ is evidenced in the Morro de Moravia open-air landfill in the city of Medellín. Likewise, animal species that inhabit this place such as different arachnids and the house mouse (Mus musculus) presented average levels of $5.01 \mathrm{mg} / \mathrm{kg}$ and $45.05 \mathrm{mg} / \mathrm{kg}$, respectively, exceeding the values of $0.5-7 \mathrm{mg} / \mathrm{kg}$ for species in uncontaminated sites [66]. Regarding plant species, the $\mathrm{Pb}$ content ranged from 0.125 to $123.7 \mathrm{mg} / \mathrm{kg}$, of which the maximum value was obtained from L. virginicum [67]. In contrast, in the areas where charcoal extraction is carried out in the municipalities of La Loma and La Jagua in the department of Cesar, lead was found in the liver tissue of house mice with values of 0.18 and $0.35 \mu \mathrm{g} / \mathrm{g}$, respectively. However, meteorological conditions were considered as variables that influenced the low concentrations, since the sampling was carried out after rainy periods [68]. Similarly, in the municipality of Los Córdobas, department of Córdoba, $\mathrm{Pb}$ was found in muscle tissue and in the liver of bats with concentrations between $0.051-0.066 \mu \mathrm{g} / \mathrm{g}$ and $0.020-0.038 \mu \mathrm{g} / \mathrm{g}$, respectively.

Other animal species such as hummingbirds of the Bogotá Savanna were used as bioindicators of $\mathrm{Pb}$, obtaining an average concentration of $3.25 \mathrm{ppm}$ in the Encenillo Reserve, in the municipality of Guasca, 4.05 ppm in the Hacienda San Carlos of the municipality of Zipacón, and 4.69 ppm on the campus of the Universidad de los Andes in the city of Bogotá [69]. These values were associated with the environmental contamination of the areas produced by mining activities and nearby roads. On the other hand, mollusks are considered biomarkers of environmental pollution in coastal areas due to their bioaccumulation capacity. For this reason, Valdelamar-Villegas \& Olivero-Verbel [70] reported $\mathrm{Pb}$ levels of 0.110 , 0.060 and $0.100 \mu \mathrm{g} / \mathrm{g}$ in the Berrugas, Cartagena, and Rioacha beaches respectively, associated with artisanal fishing.

The lead content in the tissues of animal species can come from the application of fertilizers and/or pesticides in the food they consume or in areas surrounding them. It is higher in carnivores because they are in a higher link of the food chain and consequently bioaccumulate the metal. Other variables that influence exposure to this pollutant are meteorological conditions, which affect its bioavailability, for example during the rainy season [71].

On the other hand, studies carried out on plant species have focused on those that remove and accumulate the contaminant in their tissues without phytotoxic effects [72], through analysis of the concentrations of lead in leaves, roots, and stems. In the case of Rhizophora 
mangle located in the Ciénaga Grande of Santa Marta, higher levels of $\mathrm{Pb}$ were found in its roots with values of 7.2 to $27.92 \mu \mathrm{g} / \mathrm{g}$, although different organs were analyzed, which shows a fixation mechanism in the roots that prevents the metal contained in the sediments from being transported to the rest of the plant [73], [74]. Similarly, in the upper basin of the Bogotá River values of 7.63, 7.38, 7.78 and $45.02 \mathrm{mg} / \mathrm{Kg}$ of $\mathrm{Pb}$ were reported in individuals collected in the municipality of Villapinzón of Lycianthes lycioides (L.) Hassl. in leaves, stems, roots, and soil, respectively; while for the samples collected in the municipality of Tenjo the values were $3.01,3.18,3.77$ and $4.60 \mathrm{mg} / \mathrm{kg}$, respectively. The difference in metal concentrations was associated with the contamination of the Bogotá river with discharge from tanneries [75]. Likewise, in the municipality of Villapinzón, department of Cundinamarca, different species of lichens were evaluated as bioindicators, which presented a range of 4.1 to $25.8 \mathrm{ppm}$ of lead [76].

\section{Lead Levels in Soil}

Currently, the country does not have a regulation on soil quality, therefore lead levels obtained were compared with international standards. Also, it is necessary to take into account that the concentration of the different chemical elements present in the soil is the result of its geological formation and the interaction of natural factors, and thus the identification of toxic elements in it does not necessarily suggest contamination processes. [77].

In soils for agricultural use, the content of metals such as lead is a threat to human health due to its incorporation into the food chain. Soils can become contaminated as a consequence of the deposition of industrial atmospheric emissions, application of pesticides and fertilizers, or by contact with contaminated irrigation water [78]. As an example of the last case, an average concentration of $15.11 \mathrm{mg} / \mathrm{kg}$ in summer (dry season) and $14.52 \mathrm{mg} / \mathrm{kg}$ in winter (rainy season) was found in soils dedicated to rice cultivation, irrigated with water from the Guatiquía River [77], which correspond to values within the natural range of 10 to $30 \mathrm{mg} / \mathrm{kg}$ [78]. Similar results were found for the common chard (Beta vulgaris L.) which, with a lead level in the soil of $14.7 \mathrm{mg} / \mathrm{kg}$, showed optimal growth without physiological alterations [7]. On the other hand, the lowest $\mathrm{Pb}$ values were reported in soils of rice, cotton, and pasture crops irrigated with water from the Sinú River, with maximum values of 0.059, 0.072, and $0.083 \mathrm{mg} / \mathrm{kg}$, respectively [78], exceeding the reference level for uncontaminated soils in Colombia of $0.012 \mathrm{mg} / \mathrm{kg}$ and classified as moderately contaminated [79].

Regarding urban soils, the $\mathrm{Pb}$ content in road sediments in the city of Bogotá was studied and it was determined that the highest concentrations occur in particles smaller than $63 \mu \mathrm{m}$ and during the dry season, with mean values of 107, 84, 97 and $69 \mathrm{mg} / \mathrm{kg}$ for the localities (districts) of Fontibón, Barrios Unidos [80], Kennedy, and Puente Aranda [81], respectively. 
These areas are recognized as industrial zones and exceed the limit of $60 \mathrm{mg} / \mathrm{kg}$ established by the legislation of Catalonia (Spain) but are below Canadian regulations $(140 \mathrm{mg} / \mathrm{kg})$. Similar results were obtained in the municipality of Soacha, with a concentration of 99 and $258 \mathrm{mg} / \mathrm{kg}$ for the urban center and the main road [82]. The aforementioned levels are a consequence of the emission of combustion gases, fuel and/or lubricant leaks, wear of tires and/or brakes, rust and car body rust, as well as resuspension of atmospheric particles due to vehicular traffic [83]. Similarly, Trujillo-González et al. [84] analyzed the lead content in road sediment samples from the city of Villavicencio, as categorized into three sectors: residential, commercial, and road infrastructure. The commercial sector presented an average value of $1289.4 \mathrm{mg} / \mathrm{kg}$, followed by the main road with $87.5 \mathrm{mg} / \mathrm{kg}$, and the residential area with $26 \mathrm{mg} / \mathrm{kg}$. According to both studies, a higher lead content is evidenced in road sediments in industrial urban areas due to their vehicular density and the contribution of atmospheric emissions that are deposited on the ground. This puts the health of local inhabitants at risk since the wind and the turbulence generated by the traffic can resuspend and transport the particulate matter [82].

\section{Air Pollution}

Colombian legislation [85] establishes as the maximum permissible levels in air for unconventional pollutants with carcinogenic effects, such as $\mathrm{Pb}$, values of 0.5 and $1.5 \mu / \mathrm{m}^{3}$ in terms of annual exposure and in 24 hours, respectively. In the locality (district) of Puente Aranda, in the city of Bogotá, daily average concentrations of 1.445 and $3.926 \mu \mathrm{g} / \mathrm{m}^{3}$ were found for the first monitoring campaign (June-July 2005), 1.386 and $4.994 \mu \mathrm{g} / \mathrm{m}^{3}$ for the second (October-November 2005), and 0.746 and $3.880 \mu \mathrm{g} / \mathrm{m}^{3}$ for the third (April-May 2006). The highest values, which exceed more than twice the limit established in Colombian regulations, correspond to an area close to a mass transportation main line and to 6 main roads associated with an industrial area with high traffic flow, in which wind also converges and subsequently drags pollutants to the place [86]. However, in a following study [87] an annual average level of $0.025 \mu \mathrm{g} / \mathrm{m} 3$ and a daily maximum of $1.48 \mu \mathrm{g} / \mathrm{m} 3$ were identified, associated with high-temperature industrial emissions, such as those coming from metallurgical processes, fossil fuel combustion, incineration of industrial waste, and industries related to steel, ceramics, glass, and paint manufacturing.

Similar results were found in the sampling of different areas of the city of Medellín where 360 children resided, all under 5 years of age and with respiratory diseases, obtaining values between 0.099 and $1.464 \mu / \mathrm{m}^{3}$ for Andalusia, Robledo, downtown Medellín, Castilla, Belén de los Alpes, Guayabal, Estadio, and Santa Elena. The previous results are directly related to amounts of particulate matter PM10 and PM2.5 that exceed the limits established by 
Colombian regulations [85], which in turn increases the risk of respiratory infections by $49.3 \%$ [88].

On the other hand, in the department of La Guajira, lead concentrations were evaluated in daily samplings of PM10 and PST in a high vehicular traffic area in the city of Rioacha, with average values of 7.9 and $4.1 \mathrm{ng} / \mathrm{m}^{3}$; far below the limit established for daily exposure [89]. Likewise, Fagundo and Doria [90] compared the lead levels associated with PM10 in the city of Rioacha (control) with an open-pit coal mining activity area in the municipalities of Hatonuevo, Albania, and Barrancas. Annual values of 0.006 and $0.02 \mu / \mathrm{m}^{3}$ were found in the last two sites, in contrast to the control zone, where the metal was not detected. Lead concentrations were higher in the dry season, favored by the resuspension of particles caused by the wind, excavation activities, extraction, material transport, and vehicular traffic. Similar cases were found in Manizales due to the proximity to industrial emissions, which were associated with thyroid cancer [91] and in Medellín due to emissions from the incineration of hazardous waste [92].

Lead concentration in the air can also be assessed from inside infrastructure. Thus, for example, in the study by Fuentes and Falla [93], it was determined that exposure to lead inside kindergartens in the localities (districts) of Puente Aranda, Fontibón, and Kennedy in the city of Bogotá is above the reference dose established by the EPA $\left(>1.0 \times 10^{-7} \mathrm{mg} / \mathrm{kg}\right.$ day), associated with high traffic areas, the presence of live barriers, and proximity to industries.

\section{Water Contamination}

Lead concentrations have been reported in sediments in the mangroves located at the river mouth of the Sevilla River in the Ciénaga Grande of Santa Marta [74]. Lead levels have also been reported in the streambed of the Sinú River, an area known for its intense agricultural, fish and livestock farming activity. Values reported varied between $10.10-26.89 \mathrm{mg} / \mathrm{kg}$ in the rainy season and $13.95-28.08 \mathrm{mg} / \mathrm{kg}$ in the dry season, which surpass the reference value of $9 \mathrm{mg} / \mathrm{kg}$ and resemble slightly contaminated sediments $(25.4-63.4 \mathrm{mg} / \mathrm{kg}$ ) as reported by secondary sources [94]. Likewise, Tejeda-Benítez et al. [95] analyzed sediment samples in the Magdalena River, finding an average $\mathrm{Pb}$ concentration of $12.1 \mu \mathrm{g} / \mathrm{g}$ and maximum values of $18.1 \mu \mathrm{g} / \mathrm{g}$ downstream from the city of Neiva, $18 \mu \mathrm{g} / \mathrm{g}$ in the municipality of Gamarra and $16.8 \mu \mathrm{g} / \mathrm{g}$ in the city of Barranquilla, with concentration factors of 1.29 , and 1.2 , this indicates a moderate level of contamination associated with activities such as agriculture, fishing, and mining in the first two places, while in the city of Barranquilla the petrochemical, metallurgical, construction, and port industries stand out as sources. Additionally, fluvial sediments, along with their pollutants, are carried by the Magdalena River to the bays of Cartagena and Barbacoas — with lead levels of up to $23.03 \mu \mathrm{g} / \mathrm{g}$ and $13.03 \mu \mathrm{g} / \mathrm{g}$, respectively 
[96]. Although these figures do not exceed the value of $31 \mu \mathrm{g} / \mathrm{g}$ defined as the minimum effect level for aquatic organisms, they can affect the health and diversity of the coral reef communities in the Rosario Islands.

Regarding lentic ecosystems, in 2006 lead concentrations were determined in the sediments of the La Fe reservoir, located in the department of Antioquia, with mean values of 31.66 $\mu \mathrm{g} / \mathrm{g}$ near the dam and $21.39 \mu \mathrm{g} / \mathrm{g}$ in the tail-end of the reservoir, associated with the agricultural and livestock activities developed along the channels that feed it [97]. Similarly, in the Ciénaga de Ayapel wetland complex, Rúa Cardona et. al [98] reported lead levels between 1.09-11.87 $\mu \mathrm{g} / \mathrm{g}$. The maximum value reported occurred in the center of the Ciénaga de Ayapel, which receives the water from streams contaminated by activities such as agriculture, livestock farming, mining, untreated wastewater discharge, and transportation of boats. In this case, the authors took $2.39 \mu \mathrm{g} / \mathrm{g}$ as a reference level, as found in sediment samples from the Formación Betulia near the urban center of the municipality of Ayapel. This shows an enrichment of $\mathrm{Pb}$ in the wetland complex, since $91 \%$ of the samples exceed this level. In contrast, the lead levels determined by Romero Núñez et al. [99] in the Ayapel, Lorica, and Betancí marshes are well below the reference level, with values close to $0.2 \mu \mathrm{g} / \mathrm{g}$.

On the other hand, it was found that the sediments of the bays of Cartagena and Barbacoas, affected by the pollution plumes of the rivers that flow into them, were below the permissible limits [100], while the marine sediments in the Gulf of Urabá, into which the waters of the Atrato, León, Turbo, and Caimán rivers flow, and which are contaminated by activities such as gold mining, banana plantations, extensive cattle farming, and discharge of domestic wastewater, had $\mathrm{Pb}$ levels of 0.17-6.93 $\mu \mathrm{g} / \mathrm{g}$ [101], which are below the reference value for the earth's crust $(12.5 \mu \mathrm{g} / \mathrm{g})$. In the bay of Cispatá, the economy is based on fishing, with contributions from wood production, the growth of tourism, and an oil port $12 \mathrm{~km}$ away. Here, it was reported a maximum $\mathrm{Pb}$ concentration of $1.39 \mu \mathrm{g} / \mathrm{g}$, associated with runoff contaminated with agrochemical residues and domestic wastewater [96]. In another study, levels between 5.7 and $22.4 \mu \mathrm{g} / \mathrm{g}$ of lead were found in marine sediments in the port of the city of Santa Marta, associated with the load and transportation of coal [102]. These values are below the limits established for marine sediments in the North American $(450 \mu \mathrm{g} / \mathrm{g})$ and Chinese $(60 \mu \mathrm{g} / \mathrm{g})$ regulations, but when compared with the marine sediment pollution index (MSPI) are found in the range of average and poor condition sediments.

Also, lead was reported in samples of water bodies associated with the mining activity of the department of Boyacá, with a range between 0.013-0.21 mg/L [103], exceeding the maximum limit of $0.01 \mathrm{mg} / \mathrm{L}$ established for water for human consumption [50]. Likewise, in the Las Torres stream, in the municipality of Sogamoso, there were $\mathrm{Pb}$ concentrations between $0.698-0.750 \mathrm{mg} / \mathrm{L}$ [104], exceeding the $0.1 \mathrm{mg} / \mathrm{L}$ limit for livestock use defined in Decree 1076 of 2015 [105]. These concentrations are the consequence of the discharges from the brick industry, coal mining, and wastewater from nearby communities [104]. 
Table 1. Identification of the studied environmental matrices.

\begin{tabular}{|c|c|c|c|c|c|c|}
\hline \multirow{2}{*}{ 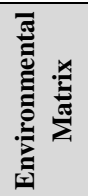 } & \multirow{2}{*}{ 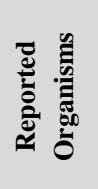 } & \multirow{2}{*}{ 离 } & \multirow{2}{*}{ Location } & \multicolumn{2}{|c|}{ Concentration } & \multirow{2}{*}{ 巡 } \\
\hline & & & & Reported $^{1}$ & $\begin{array}{l}\text { Maximum } \\
\text { allowed }\end{array}$ & \\
\hline \multirow{9}{*}{$\frac{\overline{8}}{\frac{8}{n}}$} & \multirow{5}{*}{$\frac{\bar{D}}{\stackrel{0}{0}}$} & 2004 & $\begin{array}{c}\text { Cartagena: Torices, San } \\
\text { Francisco, Barrio Chino, } \\
\text { Alcibia, Olaya, Bosque, } \\
\text { Henequén and Arroz } \\
\text { Barato }\end{array}$ & $1-21 \mu \mathrm{g} / \mathrm{dL}$ & $5 \mu \mathrm{g} / \mathrm{dL}$ & [31] \\
\hline & & $\begin{array}{l}2004- \\
2005\end{array}$ & Bogotá D.C. and Soacha & $\begin{array}{c}\text { Between } 20 \text { and } \\
90 \mu \mathrm{g} / \mathrm{dL}\end{array}$ & & [20] \\
\hline & & 2010 & North of Cali & $1.1-9.9 \mu \mathrm{g} / \mathrm{dL}$ & & [32] \\
\hline & & 2014 & $\begin{array}{c}\text { Cartagena: Canapote, } \\
\text { Paseo Bolívar, Ceballos, } \\
\text { Bosque and Zaragocilla }\end{array}$ & $0.05-34.05 \mu \mathrm{g} / \mathrm{dL}$ & & [34] \\
\hline & & 2015 & $\begin{array}{c}\text { Cartagena, Valledupar, } \\
\text { La Paz } \\
\text { Tasajera }\end{array}$ & $\begin{array}{c}<5 \mu \mathrm{g} / \mathrm{dL} \\
\text { (Cartagena, } \\
\text { Valledupar, La Paz) } \\
\mathbf{8 . 9} \\
\mathbf{0 . 8} \boldsymbol{\mu \mathbf { g } / \mathbf { d L }} \\
\text { (Tasajera) }\end{array}$ & & [35] \\
\hline & \multirow{4}{*}{$\frac{\mathscr{\vartheta}}{3}$} & 1996 & Bogotá D. C. & 15 a $369 \mu \mathrm{g} / \mathrm{dL}$ & $38 \mu \mathrm{g} / \mathrm{dL}$ & [28] \\
\hline & & $\begin{array}{l}2009- \\
2010\end{array}$ & Cali & $>5 \mu \mathrm{g} / \mathrm{dL}$ & & [38] \\
\hline & & 2012 & Cali & 62 and $90.3 \mu \mathrm{g} / \mathrm{dL}$ & & [13] \\
\hline & & 2013 & $\begin{array}{l}\text { La Mojana region: } \\
\text { Guaranda, Sucre, } \\
\text { Majagual and San } \\
\text { Marcos, Montería }\end{array}$ & $0.15-52.46 \mu \mathrm{g} / \mathrm{L}$ & & [39] \\
\hline $\begin{array}{l}\frac{n}{0} \\
\frac{\mathscr{U}}{0} \\
0\end{array}$ & $\stackrel{\mathscr{\Xi}}{\stackrel{\Xi}{\Xi}}$ & 2014 & Bogotá D.C. & 5-47600 ppm & $90 \mathrm{ppm}$ & [41] \\
\hline \multirow{3}{*}{$\begin{array}{l}8 \\
8 \\
0\end{array}$} & \multirow{2}{*}{$\stackrel{\bar{d}}{\infty}$} & $\begin{array}{c}2008- \\
2009\end{array}$ & $\begin{array}{c}\text { Sinú and San Jorge river } \\
\text { valleys, department of } \\
\text { Córdoba }\end{array}$ & $0.007-0.098^{2} \mu \mathrm{g} / \mathrm{g}$ & $0.5 \mu \mathrm{g} / \mathrm{g}$ & [52] \\
\hline & & 2014 & $\begin{array}{c}\text { Yondó and } \\
\text { Barrancabermeja, } \\
\text { Middle Magdalena }\end{array}$ & $\begin{array}{c}0.38-0.62 \text { and } 0.22- \\
0.24 \mathrm{mg} / \mathrm{kg}\end{array}$ & $\begin{array}{l}0,5 \text { and } 0,1 \\
\mathrm{mg} / \mathrm{kg}\end{array}$ & [53] \\
\hline & $\begin{array}{l}\bar{\pi} \\
\stackrel{\pi}{\mathscr{n}}\end{array}$ & 2010 & Bogotá D. C. & $\mathrm{Up}$ to $1 \mathrm{mg} / \mathrm{kg}$ & $2 \mathrm{mg} / \mathrm{kg}$ & [51] \\
\hline
\end{tabular}

${ }^{1}$ Values highlighted in bold correspond to those above the limits established by regulations or the reference values used by each study.

${ }^{2} 1 \mu \mathrm{g} / \mathrm{g}$ is equivalent to $1 \mathrm{mg} / \mathrm{Kg}$. 


\begin{tabular}{|c|c|c|c|c|c|c|}
\hline \multirow{2}{*}{ 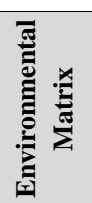 } & \multirow{2}{*}{ 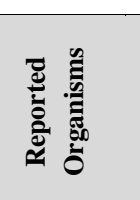 } & \multirow{2}{*}{ 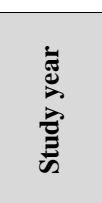 } & \multirow{2}{*}{ Location } & \multicolumn{2}{|c|}{ Concentration } & \multirow{2}{*}{ : } \\
\hline & & & & Reported $^{1}$ & $\begin{array}{l}\text { Maximum } \\
\text { allowed }\end{array}$ & \\
\hline & 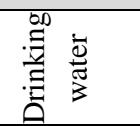 & 2012 & $\begin{array}{l}\text { Cali: communes } 13,14, \\
15 \text { and } 21\end{array}$ & $0.11-0.36 \mu \mathrm{g} / \mathrm{L}$ & $10 \mu \mathrm{g} / \mathrm{L}$ & [49] \\
\hline & $\begin{array}{l}0 \\
\text { हैँ } \\
0\end{array}$ & 2014 & Tunja (Boyacá) & $0.085-0.150 \mathrm{mg} / \mathrm{Kg}$ & $0.1 \mathrm{mg} / \mathrm{kg}$ & [47] \\
\hline & 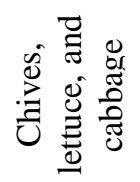 & 2015 & $\begin{array}{l}\text { Toledo, Norte de } \\
\text { Santander }\end{array}$ & $0.01-0.38$ & $0.3 \mathrm{mg} / \mathrm{kg}$ & [48] \\
\hline & & 2005 & $\begin{array}{c}\text { Chocontá and Suesca } \\
\text { municipalities } \\
\text { (department of } \\
\text { Cundinamarca) }\end{array}$ & 7.7 and $7.3 \mathrm{ppm}$ & $\begin{array}{l}0.3 \mathrm{mg} / \mathrm{kg} \\
0.3 \mathrm{mg} / \mathrm{kg}\end{array}$ & [56] \\
\hline & & $\begin{array}{l}2011- \\
2012\end{array}$ & $\begin{array}{c}\text { Ciénaga de Mallorquín } \\
\text { (Barranquilla) }\end{array}$ & $0.66-2.03 \mu \mathrm{g} / \mathrm{g}$ & & [57] \\
\hline & $\frac{\pi}{\infty}$ & 2014 & $\begin{array}{c}\text { Vereda Volcán (Paipa, } \\
\text { Boyacá) }\end{array}$ & $0.12-0.51 \mu \mathrm{g} / \mathrm{g}$ & & [58] \\
\hline & 告 & n.d. & $\begin{array}{c}\text { Urabá Gulf: Candelaria } \\
\text { Bay, Marirrío Bay, } \\
\text { Bocas del Roto and } \\
\text { Bocas del Atrato }\end{array}$ & $0.667-23.378 \mathrm{mg} / \mathrm{kg}$ & & [59] \\
\hline & & 2014 & Bogotá D.C. & $0.016-0.089 \mathrm{mg} / \mathrm{kg}$ & & [60] \\
\hline & & 2016 & Atrato river delta & $\begin{array}{c}0.672 \text { to } 3.110 \mathrm{mg} \\
\mathrm{kg}\end{array}$ & & [61] \\
\hline & 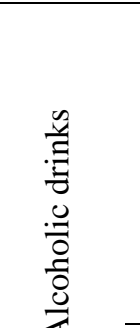 & n.d. & $\begin{array}{c}\text { Rocha, Ballesta, Puerto } \\
\text { Badel, Santa Rosa, } \\
\text { Villanueva, Turbaco, } \\
\text { San Basilio de } \\
\text { Palenque, María la Baja, } \\
\text { Arroyo Hondo, } \\
\text { Pasacaballos } \\
\text { municipalities (Bolívar) }\end{array}$ & $0.5-0.76 \mathrm{mg} / \mathrm{L}$ & $0,1-0,3 \mathrm{mg} / \mathrm{L}$ & [62] \\
\hline & & n.d. & $\begin{array}{c}\text { Galeras, Sincé, and } \\
\text { Morroa municipalities } \\
\text { (Sucre) }\end{array}$ & $0.36-0.41 \mathrm{mg} / \mathrm{L}$ & & [63] \\
\hline \multirow{4}{*}{$\overline{\overline{0}}$} & \multirow{4}{*}{ 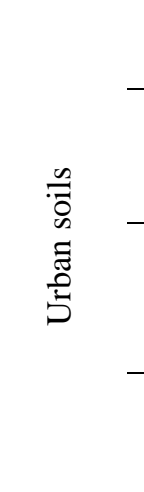 } & 2010 & Soacha (Cundinamarca) & 99 and $258 \mathrm{mg} / \mathrm{kg}$ & $60 \mathrm{mg} / \mathrm{kg}$ & [82] \\
\hline & & $\begin{array}{l}2010- \\
2011\end{array}$ & $\begin{array}{l}\text { Localities (districts) of } \\
\text { Kennedy and Puente } \\
\text { Aranda in Bogotá D. C. }\end{array}$ & 97 and $69 \mathrm{mg} / \mathrm{kg}$ & & [81] \\
\hline & & $\begin{array}{l}2010- \\
2011\end{array}$ & $\begin{array}{l}\text { Localities (districts) of } \\
\text { Fontibón and Barrios } \\
\text { Unidos in Bogotá D. C. }\end{array}$ & 107 and $84 \mathrm{mg} / \mathrm{kg}$ & & [80] \\
\hline & & 2014 & Villavicencio & $\begin{array}{l}\text { Commercial area } \\
1289.4 \mathrm{mg} / \mathrm{kg} \text {, main } \\
\mathrm{road} 87.5 \mathrm{mg} / \mathrm{kg}\end{array}$ & & [83] \\
\hline
\end{tabular}




\begin{tabular}{|c|c|c|c|c|c|c|}
\hline \multirow{2}{*}{ 嵒 } & \multirow{2}{*}{ 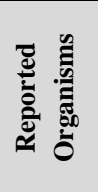 } & \multirow{2}{*}{ 离 } & \multirow{2}{*}{ Location } & \multicolumn{2}{|c|}{ Concentration } & \multirow{2}{*}{ 巡 } \\
\hline & & & & Reported $^{1}$ & $\begin{array}{l}\text { Maximum } \\
\text { allowed }\end{array}$ & \\
\hline \multicolumn{7}{|c|}{$\begin{array}{l}\text { and residential } \\
\text { area } 26 \mathrm{mg} / \mathrm{kg}\end{array}$} \\
\hline & \multirow{3}{*}{ 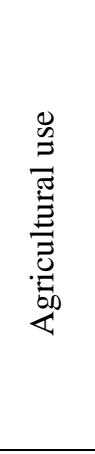 } & n.d. & Bogotá D. C. & $14.7 \mathrm{mg} / \mathrm{kg}$ & $10-30 \mathrm{mg} / \mathrm{kg}$ & [18] \\
\hline & & $\begin{array}{l}2011- \\
2012\end{array}$ & $\begin{array}{l}\text { Vereda La Esperanza } \\
\text { (Villavicencio, Meta) }\end{array}$ & $\begin{array}{l}15.11 \mathrm{mg} / \mathrm{kg} \text { in the } \\
\text { dry season and } 14.52 \\
\mathrm{mg} / \mathrm{kg} \text { in the rainy } \\
\text { season }\end{array}$ & & [77] \\
\hline & & 2015 & $\begin{array}{l}\text { Lower and middle basin } \\
\text { of the Sinú river, } \\
\text { between the } \\
\text { departments of Córdoba } \\
\text { and Antioquia }\end{array}$ & $0.13 \mathrm{mg} / \mathrm{kg}$ & $0.012 \mathrm{mg} / \mathrm{kg}$ & [78] \\
\hline & 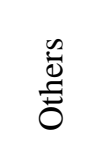 & n.d. & $\begin{array}{l}\text { Tenjo and Villapinzon } \\
\text { municipalities } \\
\text { (department of } \\
\text { Cundinamarca) }\end{array}$ & $45.02 \mathrm{mg} / \mathrm{kg}$ & $10-30 \mathrm{mg} / \mathrm{kg}$ & [75] \\
\hline \multirow{4}{*}{ 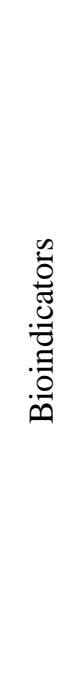 } & $\frac{\mathscr{D}}{\sqrt[\Xi]{0}}$ & n.d. & $\begin{array}{c}\text { Villapinzon } \\
\text { municipality } \\
\text { (department of } \\
\text { Cundinamarca) }\end{array}$ & 4.1 to $25.8 \mathrm{ppm}$ & & [76] \\
\hline & 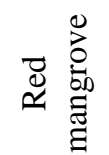 & 2003 & $\begin{array}{l}\text { River mouth of the } \\
\text { Sevilla river-Ciénaga } \\
\text { Grande de Santa Marta }\end{array}$ & 7.2 to $27.92 \mu \mathrm{g} / \mathrm{g}$ & & [73] \\
\hline & \multirow[t]{2}{*}{$\frac{a}{\tilde{\Xi}}$} & n.d. & $\begin{array}{l}\text { Tenjo and Villapinzon } \\
\text { municipalities } \\
\text { (department of } \\
\text { Cundinamarca) }\end{array}$ & $\begin{array}{c}7.63,7.38,7.78 \\
\mathrm{mg} / \mathrm{kg}\end{array}$ & & [75] \\
\hline & & 2008 & Medellín & $\begin{array}{c}0.125 \text { to } 123.7 \\
\mathrm{mg} / \mathrm{kg}\end{array}$ & & [66] \\
\hline \multirow{4}{*}{ 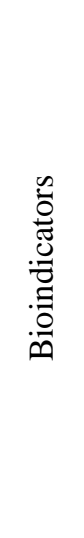 } & 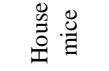 & 2008 & Medellín & $5.02-45.05 \mathrm{mg} / \mathrm{kg}$ & $0.5-7 \mathrm{mg} / \mathrm{kg}$ & [67] \\
\hline & 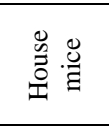 & $\begin{array}{l}2010- \\
2011\end{array}$ & $\begin{array}{l}\text { Department of Cesar: La } \\
\text { Loma, La Jagua and } \\
\text { Valledupar }\end{array}$ & 0.18 and $0.35 \mu \mathrm{g} / \mathrm{g}$ & & [68] \\
\hline & 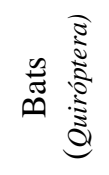 & 2012 & $\begin{array}{c}\text { Los Córdobas } \\
\text { municipality, } \\
\text { department of Córdoba }\end{array}$ & $\begin{array}{l}0.051-0.066 \mu \mathrm{g} / \mathrm{g} \text { in } \\
\text { liver tissue and } \\
0.020-0.038 \mu \mathrm{g} / \mathrm{g} \text { in } \\
\text { muscle tissue }\end{array}$ & & [71] \\
\hline & 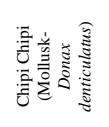 & $\begin{array}{l}2012- \\
2013\end{array}$ & $\begin{array}{l}\text { Berrugas (Sucre), } \\
\text { Cartagena (Bolívar), } \\
\text { Riohacha (Guajira) }\end{array}$ & $\begin{array}{c}0.110,0.060 \text { and } \\
0.100 \mu \mathrm{g} / \mathrm{g}\end{array}$ & & [70] \\
\hline
\end{tabular}




\begin{tabular}{|c|c|c|c|c|c|c|}
\hline \multirow{3}{*}{ 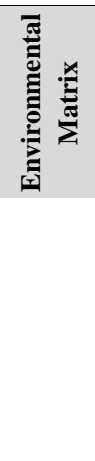 } & \multirow{2}{*}{ 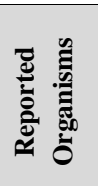 } & \multirow{2}{*}{ 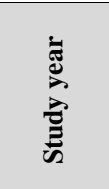 } & \multirow{2}{*}{ Location } & \multicolumn{2}{|c|}{ Concentration } & \multirow{2}{*}{$\frac{\mathscr{E}}{\mathscr{e}}$} \\
\hline & & & & Reported $^{1}$ & $\begin{array}{l}\text { Maximum } \\
\text { allowed }\end{array}$ & \\
\hline & 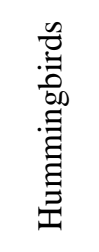 & 2015 & $\begin{array}{c}\text { Biological Reserve El } \\
\text { Encenillo (Guasca); } \\
\text { Hacienda San } \\
\text { Carlos (Zipacón); } \\
\text { Universidad } \\
\text { de los Andes (Bogotá) }\end{array}$ & $\begin{array}{c}3.25,4.05 \text { and } 4.69 \\
\text { ppm }\end{array}$ & & [69] \\
\hline \multirow{5}{*}{ 妾 } & \multirow{3}{*}{ 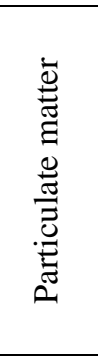 } & $\begin{array}{l}2005- \\
2006\end{array}$ & $\begin{array}{c}\text { Locality (district) of } \\
\text { Puente Aranda (Bogotá } \\
\text { D. C.) }\end{array}$ & $\begin{array}{c}1.445 \text { and } 3.926 \\
\mu \mathrm{g} / \mathrm{m} 3 \text { day }\end{array}$ & $\begin{array}{c}0.5 \mu \mathrm{g} / \mathrm{m} 3 \\
\text { yearly and } 1.5 \\
\mu \mathrm{g} / \mathrm{m} 3 \text { in } 24 \\
\text { hours }\end{array}$ & [86] \\
\hline & & $\begin{array}{l}2006- \\
2007 \\
\end{array}$ & $\begin{array}{c}\text { Andalucía neighborhood } \\
\text { (Medellín) }\end{array}$ & $1.464 \mu \mathrm{g} / \mathrm{m} 3$ day & & [88] \\
\hline & & $\begin{array}{l}2011- \\
2012\end{array}$ & Rioacha (Guajira) & $7.9 \mathrm{ng} / \mathrm{m} 3$ & & [89] \\
\hline & \multirow{2}{*}{ : } & 2013 & $\begin{array}{l}\text { Albania and Barrancas } \\
\text { municipalities } \\
\text { (department of La } \\
\text { Guajira) }\end{array}$ & $\begin{array}{c}0.006 \text { and } 0.02 \\
\mu \mathrm{g} / \mathrm{m} 3\end{array}$ & & [90] \\
\hline & & $\begin{array}{l}2015- \\
2016\end{array}$ & Bogotá D. C. & $\begin{array}{c}0.025 \mu \mathrm{g} / \mathrm{m} 3 \text { yearly } \\
\text { and daily maximum } \\
\text { of } \mathbf{1 . 4 8} \boldsymbol{\mu g} / \mathbf{m} \mathbf{3}\end{array}$ & & [87] \\
\hline \multirow{4}{*}{ 离 } & \multirow{2}{*}{ 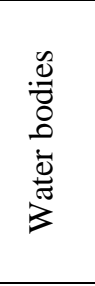 } & 2013 & $\begin{array}{c}\text { Las Torres stream, } \\
\text { Sogamoso } \\
\text { (municipality, } \\
\text { department of Boyacá) } \\
\end{array}$ & $0.75 \mathrm{mg} / \mathrm{L}$ & $\begin{array}{l}0.1 \mathrm{mg} / \mathrm{L} \text { for } \\
\text { livestock } \\
\text { farming use }\end{array}$ & [104] \\
\hline & & n.d. & Boyacá & $0.013-0.21 \mathrm{mg} / \mathrm{L}$ & $\begin{array}{l}0.01 \mathrm{mg} / \mathrm{L} \text { for } \\
\text { human } \\
\text { consumption }\end{array}$ & [103] \\
\hline & \multirow{2}{*}{ 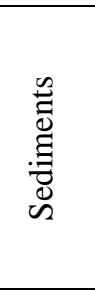 } & 2006 & $\begin{array}{l}\text { Catchment area of the } \\
\text { La Fe reservoir, } \\
\text { (department of } \\
\text { Antioquia) }\end{array}$ & $31.66 \mu \mathrm{g} / \mathrm{g}$ & & [97] \\
\hline & & $\begin{array}{l}2006- \\
2008\end{array}$ & $\begin{array}{l}\text { Ayapel marsh } \\
\text { [department of } \\
\text { Córdoba] }\end{array}$ & $1.090-11.870 \mu \mathrm{g} / \mathrm{g}$ & $2.39 \mu \mathrm{g} / \mathrm{g}$ & [98] \\
\hline \multirow{4}{*}{ 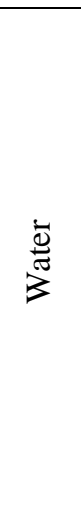 } & \multirow{4}{*}{$\begin{array}{l}\stackrel{0}{0} \\
\stackrel{0}{0} \\
\tilde{D} \\
\tilde{n}\end{array}$} & 2008 & $\begin{array}{l}\text { Ayapel, Lorica, and } \\
\text { Betanci wetlands } \\
\text { (department of } \\
\text { Córdoba) }\end{array}$ & $0.2 \mu \mathrm{g} / \mathrm{g}$ & & [99] \\
\hline & & $\begin{array}{l}2007- \\
2008\end{array}$ & Sinú river basin & $\begin{array}{c}10.10-26.89 \mathrm{mg} / \mathrm{kg} \\
\text { in the rainy season } \\
13,95-28,08 \mathrm{mg} / \mathrm{Kg} \\
\text { in the dry season }\end{array}$ & $9 \mathrm{mg} / \mathrm{Kg}$ & [94] \\
\hline & & 2009 & Urabá Gulf & $0.17-6.93 \mu \mathrm{g} / \mathrm{g}$ & $12.5 \mu \mathrm{g} / \mathrm{g}$ & [101] \\
\hline & & $\begin{array}{l}2010- \\
2011\end{array}$ & Cispatá bay & $1.39 \mu \mathrm{g} / \mathrm{g}$ & & [96] \\
\hline
\end{tabular}




\begin{tabular}{|c|c|c|c|c|c|c|}
\hline \multirow{2}{*}{ 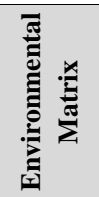 } & \multirow{2}{*}{ 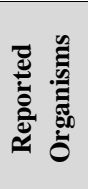 } & \multirow{2}{*}{ 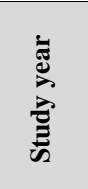 } & \multirow{2}{*}{ Location } & \multicolumn{2}{|c|}{ Concentration } & \multirow{2}{*}{ : } \\
\hline & & & & Reported $^{1}$ & $\begin{array}{l}\text { Maximum } \\
\text { allowed }\end{array}$ & \\
\hline & & 2011 & Santa Marta port & $5.722 .4 \mu \mathrm{g} / \mathrm{g}$ & $60 \mu \mathrm{g} / \mathrm{g}$ & {$[102]$} \\
\hline & & 2013 & Magdalena river & $\begin{array}{c}\text { Neiva }(18.1 \mu \mathrm{g} / \mathrm{g}) \text {, } \\
\text { Gamarra }(18 \mu \mathrm{g} / \mathrm{g}) \\
\text { Barranquilla }(16.8 \\
\mu \mathrm{g} / \mathrm{g})\end{array}$ & $\begin{array}{c}\mathrm{FC}= \\
\text { moderate } \\
\text { contamination }\end{array}$ & [95] \\
\hline & & 2013 & $\begin{array}{l}\text { Cartagena and } \\
\text { Barbacoas bays }\end{array}$ & $0.59-23.03 \mu \mathrm{g} / \mathrm{g}$ & $31 \mu \mathrm{g} / \mathrm{g}$ & {$[100]$} \\
\hline
\end{tabular}

Source: Own source.

The table above shows reports of specific cases, so it cannot be assumed they are generalizable to the country. Even so, it should cause alarm that 41 of the 57 reported cases, that is, $72 \%$, show lead concentrations above the norm. These percentages, as summarized in figure 4, amount to $89 \%$ for blood samples in adults and children, $71 \%$ for food, $63 \%$ for soil, $89 \%$ for bioindicators, $60 \%$ for air and $55 \%$ for water. It can be noticed that the maximum values in most cases exceeded the acceptable levels, evidencing a greater risk of poisoning in activities related to battery recycling, consumption of contaminated food, ingestion of paint particles, and projectiles lodged in the human body. This situation is aggravated by a lack of regulations in the country related to environmental exposure to lead.

Given the complex relationships and the transport of pollutants in the environment, water sources in rural areas become areas of interest for a comprehensive analysis of different substances, taking into account that many of these sources are used in the irrigation of crops and in the water supply to communities, without purification systems that include the removal of heavy metals.

Figure 4. Cases reported according to compliance or not with the maximum permitted concentrations

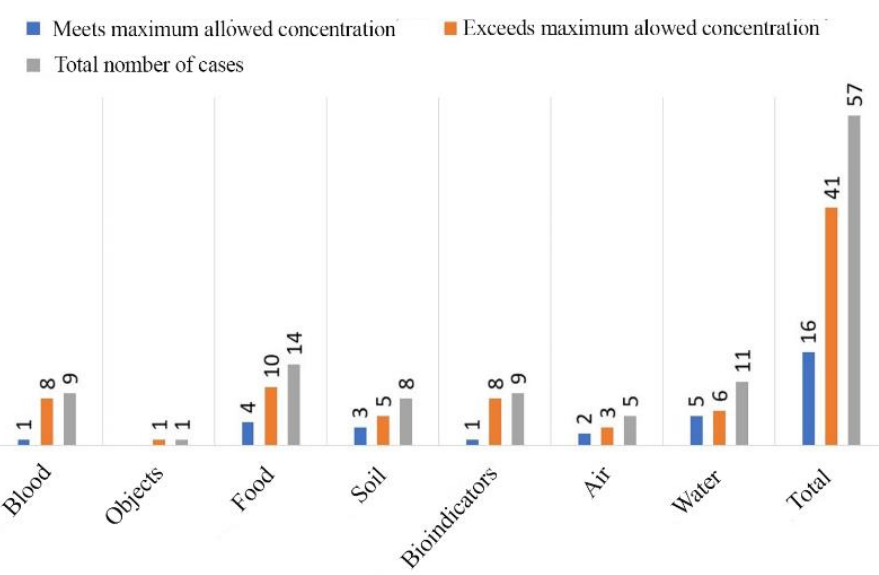

Source: Own source. 
Figure 5. Geographic location of the lead reports in Colombia

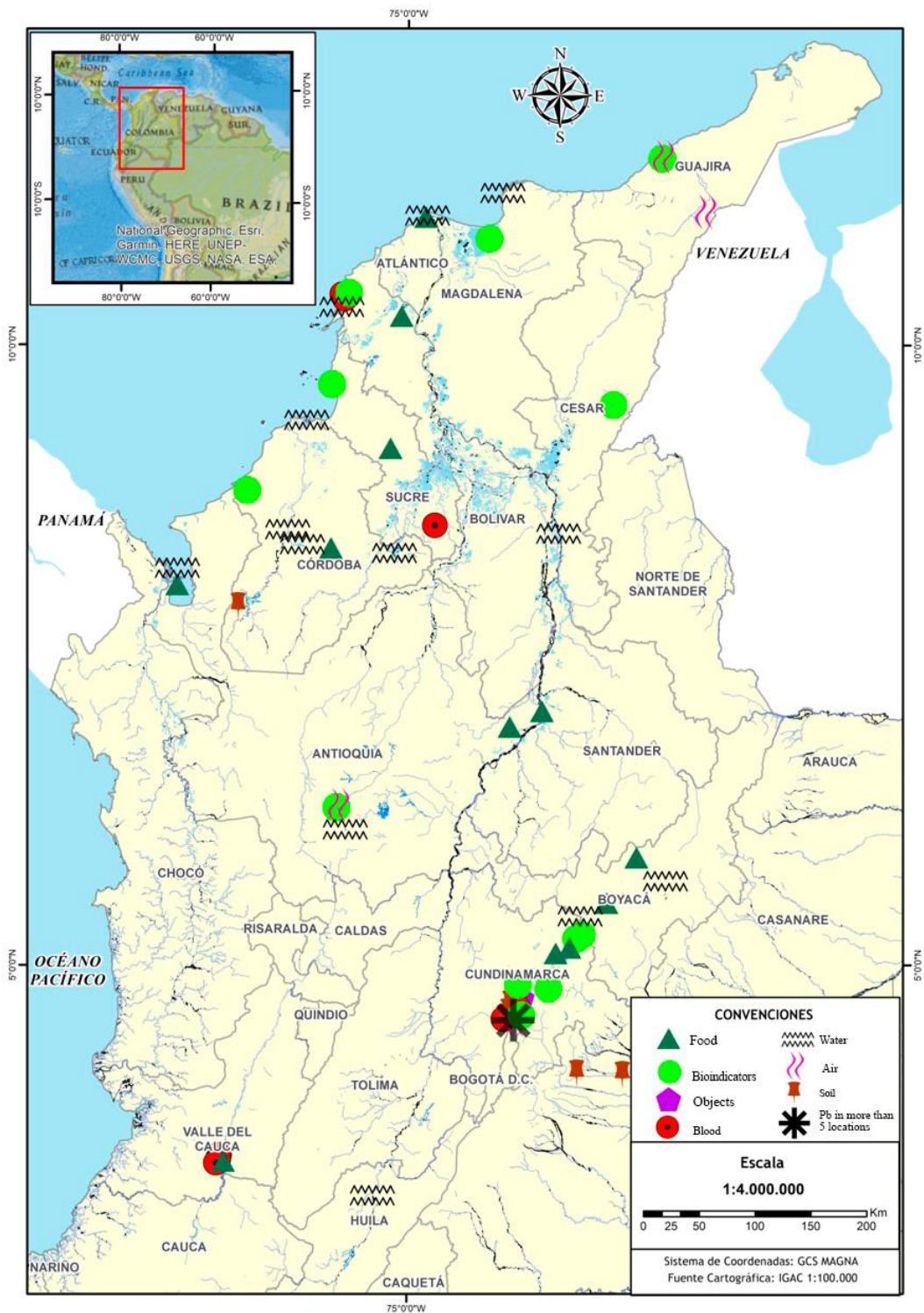

Source: own source.

\section{Conclusions}

The studies analyzed show that lead is distributed in Colombia across all environmental matrices: blood in humans, food, soil, bioindicators, air, and water. The percentages that are above the permissible values for each one are $89 \%, 71 \%, 63 \%, 89 \%, 60 \%$ and $55 \%$, respectively. These data allow us to estimate that lead poisoning could become a large-scale ecological and public health problem in the country, given its availability in the different environmental matrices. 
There is a greater risk for the population of vulnerable groups (children, the elderly and pregnant women) of low socioeconomic status and for those who live in the vicinity of car battery manufacturing or recycling industries, foundries or metalworking factories, facilities for the disposal of hazardous waste, or are close to particulate matter (PM10), oil refineries, extraction wells, industrial discharges, and for those who consume contaminated food or beverages. Despite this, there is evidence of little research on the subject.

For this reason, it becomes necessary to carry out new studies that provide a broader vision of this situation at a national level and that, in addition to determining concentrations, carry out an assessment of the health risk in different exposure scenarios, in such a way that they can guide public policies and regulatory adjustments that benefit citizens and ecosystems. Furthermore, these studies should increase the geographic coverage. Figure 5 shows that the existing studies are located in the areas of greatest economic activity and industrial concentration in the country, showing a clear information gap in the Pacific Coast, Orinoquía and the south of the country, places where there may also be contamination by lead.

Although it was found that $72 \%$ of the studies reported lead concentrations that exceed the values defined by the regulations, it must be considered that the results presented follow the inclusion and exclusion criteria defined. Although these criteria were adopted to present as realistic a picture as possible, changing them would have yielded different results. For example, taking information from studies with secondary information or that did not report the specific place of the sample would have yielded a greater amount of data, but the information reported in this article would have had less rigor and geolocation of the studies would not have been possible. Similarly, if articles prior to 1995 had been included, the lead conditions allowed in gasoline would have been different from the current ones and they would have been estimated with methods not comparable to the most recent ones. Likewise, including studies without specific concentrations of lead would have given us a greater geographic panorama, but it would not have allowed us to know if the concentrations represent any risk. 


\section{References}

[1] L. Wang, J. Chen, Y. Hung, and N. Shammas, Heavy metals in the Environment. Boca Raton: Taylor \& Francis, 2009.

[2] B. Volesky, and Z. Holan, "Biosorption of heavy metals," Biotechnol. Progr., vol. 11, no. 3, pp. 235250, 1995. doi: 10.1021/bp00033a001

[3] C. Patterson, "Contaminated and natural lead environments of man," Arch. Environ. Health, vol. 11, no. 3, pp. 344-360, 1965. doi: 10.1080/00039896.1965.10664229

[4] J. Téllez Mosquera and F. Marlen Bautista, "Exposición ocupacional a plomo: aspectos toxicológicos," Av. Enferm., vol. 23, no. 1, pp. 31-44, 2005. Available: https://revistas.unal.edu.co/index.php/avenferm/article/view/37755

[5] J. Vega, A. Contreras, E. Ríos, N. Marchetti, and M. Agurto, "Exposición al plomo y sus efectos en la salud infantil," Rev. Chil. Pediatr., vol. 61, no. 3, pp. 154-160, 1990. doi: 10.4067/s037041061990000300009

[6] A. Doadrio Vallejo, "Ecotoxicología y acción toxicológica del plomo," An. La. Real Acad. Nac. Farm., vol. 72, no. 3, pp. 409-422, 2006.

[7] D. Fontalvo-Rivera et al., "Toxicidad de elementos lúdicos y materiales educativos: una invitación a la concienciación,” Rev. Cienc. Bioméd., vol. 3, no. 1, pp. 90-98, 2012. Available: https://dialnet.unirioja.es/servlet/articulo?codigo $=7707027$

[8] A. Bautista and M. del Rosario, "Elementos potencialmente tóxicos en suelos agrícolas con manejo de riesgo contaminante," Natur. Desarro., vol. 4, no. 1, pp. 37-42, 2006.

[9] C. Rubio, A. Gutiérrez, R. Martín Izquierdo, C. Revert, G. Lozano, and A. Hardisson, "El plomo como contaminante alimentario," Toxicol., vol. 21, no. 3, pp. 72-80, 2004. Available: http://rev.aetox.es/wp/wp-content/uploads/hemeroteca/vol21-23/209-465-1-SM.pdf

[10]C. Zafra Mejía, J. Temprano González, and I. Tejero Monzón, "Concentración y distribución de metales pesados ( $\mathrm{Pb}, \mathrm{Zn}, \mathrm{Cu}, \mathrm{Cd}$ y $\mathrm{Cr}$ ) en sedimentos viarios urbanos,” Rev. Fac. Ing. Univ. Antioquia, no. 58, 5 p. 53-62, $2011 . \quad$ Available: https://revistas.udea.edu.co/index.php/ingenieria/article/view/14599

[11]P. Mushak, J. Davis, A. Crocetti , and L. Grant, "Prenatal and postnatal effects of low-level lead exposure: Integrated summary of a report to the U. S. congress on childhood lead poisoning," Environ. Res., vol. 50, no. 1, pp. 11-36, 1989. doi: 10.1016/S0013-9351(89)80046-5

[12] J. Gerstner Garcés, "Secondary lead poisoning a projectile housed in the human body," Colomb. Med., vol. 43, no. 3, pp. 230-234, 2012. Available: https://doi.org/10.25100/cm.v43i3.788

[13] J. C. Díaz Álvarez, "Implementación de estrategias promocionales en salud que contribuyan a la generación de estilos de vida saludable en la población localizada en la planicie aluvial baja del río Bogotá, expuesta a la contaminación por mercurio, plomo y cadmio," IEID, vol. 11, no. 1, pp. 7-31, 2011. Available: http://revistas.javeriana.edu.co/index.php/imagenydesarrollo/article/view/1606

[14] M. I. Sarmiento, Á. J. Idrovo, M. Restrepo, M. del Pilar Díaz, and A. González, "Evaluación del impacto de la contaminación del embalse del Muña sobre la salud humana," Rev. Salud Pub., vol. 1, no. $2, \quad$ pp. $159-171, \quad 1999 . \quad$ Available: https://revistas.unal.edu.co/index.php/revsaludpublica/article/view/18950

[15]C. Klaassen, "Risk assessment", en Casarett and Doull's toxicology: the basic science of poisons. New York: McGraw-Hill Education, 2013, pp. 107-128.

[16] L. Saldivar, A. Tovar, and D. Namihira, "Contaminantes inorgánicos," en Intrroducción a la toxicología ambiental. Metepec, Estado de México: Centro Panamericano de Ecología Humana y Salud, 1997, pp. 177-196. 
[17] R. Figueroa, D. Caicedo, G. Echeverry, M. Peña, and F. Mendez, "Condición socioeconómica, patrones de alimentación y exposición a metales pesados en mujeres en edad fértil de Cali, Colombia," Bioméd., vol. 37, no. 3, pp. 341-352, 2017. doi: 10.7705/biomedica.v37i3.3286

[18]D. Vega Castro and A. Salamanca Rivera, "Contenidos de plomo en acelga común Beta vulgaris L., producida en el contexto de la agricultura urbana (Bogotá, Colombia)," Luna Azul, vol. 42, pp. 4453, 2016. Available: http://www.scielo.org.co/scielo.php?pid=S1909$24742016000100005 \&$ script $=$ sci_abstract\&tlng=es

[19]Colombia, Ministerio del Medio Ambiente, Decreto 948 de 1995. [Online]. Available: http://www.minambiente.gov.co/images/normativa/app/decretos/54 dec_0948_1995.pdf

[20] J. Echeverry, C. M. Hurtado, and M. Gutiérrez, “Aspectos clínicos y niveles de plomo en niños expuestos de manera paraocupacional en el proceso de reciclaje de baterías de automóviles en las localidades de Soacha y Bogotá, D. C.," Bioméd., vol. 28, no. 1, pp. 116-125, 2008. doi: 10.7705/biomedica.v28i1.114

[21] I. Ferreira González, G. Urrútia, and P. Alonso-Coello, "Revisiones sistemáticas y metaanálisis: bases conceptuales e interpretación," Rev. Esp. Cardiol., vol. 64, no. 8, pp. 688-696. doi: 10.1016/j.recesp.2011.03.029

[22] S. G. Moncada-Hernández, "Cómo realizar una búsqueda de información eficiente. Foco en estudiantes, profesores e investigadores en el área educativa," Inves. Educ. Méd., vol. 3, no. 10, pp. 106-115, 2014. doi: 10.1016/s2007-5057(14)72734-6

[23] G. Gómez, C. Vélez, A. Ceballos, and F. J. Henao, "Revisión sistemática de los factores asociados a la presentación de gotas citoplásmicas en porcinos" Rev. Salud Púb., vol. 16, no. 6, pp. 937-946, 2016. doi: 10.15446/rsap.v16n6.44146

[24] R. A. Gómez Suárez et al., "Revisión sistemática: un enfoque para identificar desigualdades en salud a través de estudios de casos," Rev. Case Rep., vol. 2 no. I, pp. 4, 2016. Available: https://revistas.unal.edu.co/index.php/care/article/view/55267/64561

[25] J. Caravanos et al., "Blood lead levels in Mexico and pediatric burden of disease implications," Ann. Glob. Health, vol. 80, no. 4, pp. 269-277, 2014. doi: 10.1016/j.aogh.2014.08.002

[26] D. Moher, A. Liberati, J. Tetzlaff, D. G. Altman, and The PRISMA Group, "Preferred reporting items for systematic reviews and meta-analyses: The PRISMA statement," PLOS Med., vol. 6, no. 7, pp. 2009. [Online]. doi: 10.1371/journal.pmed.1000097

[27] C. Geney Celis, M. Barbosa Devia, A. Díaz Gómez, D. Pérez Castiblanco, S. Osorio García, and Y. González Álvarez, "Menores de 17 años con concentraciones de plomo por exposición ambiental en Bogotá," Univers. Med., vol. 57, no. 2, pp. 182-192, 2016. doi: 10.11144/javeriana.umed57-2.mcpe

[28] O. Cardenas-Bustamante, M. Varona-Uribe, S. Nuñez-Trujillo, J. Ortiz-Varón, and G. Peña-Parra, "Correlación de protoporfirina zinc y plomo en sangre en trabajadores de fábricas de baterías, de Bogotá, Colombia," Salud Púb., vol. 43, no. 3, pp. 203-210, 2001. doi: 10.1590/s003636342001000300005

[29] H. Cuevas, J. Ortiz, F. de la Hoz, and J. Raad, "Vigilancia de los niveles de zinc protoporfirina (ZPP) y plomo en sangre en trabajadores de una imprenta en Santa Fe de Bogotá," Bioméd., vol. 17, no. 1, pp. 56-61, 1997. doi: 10.7705/biomedica.v17i1.926

[30] O. Martinez and M. Lopez de Goenaga, "Prevalencia de alteraciones hematológicas en intoxicación ocupacional por plomo," Acta Méd. Colomb., vol. 22, no. 5, pp. 233-239, 1997. Available: http://www.actamedicacolombiana.com/anexo/articulos/05-1997-04-.pdf

[31] J. Olivero-Verbel, D. Duarte, M. Echenique, J. Guette, B. Johnson-Restrepo, and P. Parsons, "Blood lead levels in children aged 5-9 years living in Cartagena, Colombia," Sci.Total Environm., vol. 372, no. 2-3, pp. 707-716, 2007. doi: 10.1016/j.scitotenv.2006.10.025

[32] P. Filigrana and F. Méndez, "Blood lead levels in schoolchildren living near an industrial zone in Cali, Colombia: The role of socioeconomic condition," Biol. Trace Elem. Res., vol. 149, no. 3, pp. 299-306, 2012. doi: 10.1289/isee.2011.00928 
[33] Colombia, Congreso de la República, Proyecto de Ley 148 de 2015. [Online]. Available: http://leyes.senado.gov.co/proyectos/index.php/textos-radicados-senado/proyectos-de-ley-20142015/414-proyecto-de-ley-148-de-2015

[34] N. Alvarez-Ortega, K. Caballero-Gallardo, and J. Olivero-Verbel, "Low blood lead levels impair intellectual and hematological function in children from Cartagena, Caribbean coast of Colombia," J. Trace Elem. Med. Biol., vol. 44, pp. 230-240, 2017. doi: 10.1016/j.jtemb.2017.08.006

[35] N. Alvarez-Ortega, K. Caballero-Gallardo, and J. Olivero-Verbel, "Toxicological effects in children exposed to lead: A cross-sectional study at the Colombian Caribbean coast," Environ. Int., vol. 130, no. April, p. 104809, 2019. doi: 10.1016/j.envint.2019.05.003

[36]Colombia, Alcalde Mayor de Bogotá D. C., Decreto 623 de 2011. [Online]. Available: https://www.alcaldiabogota.gov.co/sisjur/normas/Norma1.jsp?i=45155

[37] S. Osorio-García et al., "Prevalencia de mercurio y plomo en población general de Bogotá 2012/2013," Rev. Salud Púb., vol. 16, no. 4, pp. 621-628, 2014. doi: 10.15446/rsap.v16n4.38675

[38] M. Suarez-Ortegón, M. Mosquera, D. Caicedo, C. de Plata, and F. Méndez, "Nutrients intake as determinants of blood lead and cadmium levels in Colombian pregnant women," Am. J. Hum. Biol., vol. 25, no. 3, pp. 344-350, 2013. doi: 10.1002/ajhb.22375

[39]C. Calao and J. Marrugo, "Efectos genotóxicos en población humana asociados a metales pesados en la región de La Mojana, Colombia," Bioméd., vol. 35, no. 2, pp. 139-151, 2015. doi: 10.7705/biomedica.v35i0.2392

[40] Colombia, Superintendecia de Industria y Comercio, Reglamento técnico sobre los requisitos sanitarios de los juguetes, sus componentes y accesorios. 2015. [Online]. Available: http://www.sic.gov.co/recursos_user/reglamentos_tecnicos/RT_Juguetes_combinado.pdf

[41] A. Mateus-García and J. Ramos-Bonilla, "Presence of lead in paint of toys sold in stores of the formal market of Bogotá, Colombia," Environ. Res., vol. 128, pp. 92-97, 2014. doi: 10.1016/j.envres.2013.11.005

[42] Colnodo, "Informe Nacional-Plomo en pinturas a base de solventes para uso doméstico en Colombia," Bogotá, Colombia, 2016. [Online]. Available: https://rds.org.co/es/recursos/informe-nacional-plomoen-pinturas-a-base-de-solventes-para-uso-domestico-en-colombia

[43] ICONTEC Norma Técnica Colombiana 1335, 2015: Pinturas al agua tipo emulsion. [Online]. Available: https://members.wto.org/crnattachments/2016/TBT/COL/16_0285_00_s.pdf

[44] Organización de las Naciones Unidas para la Alimentación y la Agricultura (FAO), "Report of the eighth session of the Codex Committee on Contaminants in Foods. 37th Session Geneva, Switzerland." 2014. [Online]. Available: http://www.fao.org/3/w0124e/W0124E01.htm.

[45] Colombia, Ministerio de Salud y Protección Social, Resolución Número 4506 de 2013. [Online]. Niveles máximos de contaminantes en los alimentos destinados al consumo humano y otras disposiciones.

Available: https://www.minsalud.gov.co/sites/rid/Lists/BibliotecaDigital/RIDE/DE/DIJ/resolucion-4506-de2013.pdf

[46] Colombia, Ministerio de Salud y Protección Social, Resolución 122 de 2012. [Online]. Available: https://www.invima.gov.co/normatividad-sp-510373846/alimentos/resoluciones alimentos/resoluciones-2012/2798-resolucion-122-enero-262012.html .

[47] Y. L. Moreno Mariño, J. M. Garcia Colmenares, and S. P. Chaparro Acuña, "Cuantificación volumétrica de plomo y cadmio en papa fresca," U. D. C. A. Actual. Divulg. Científ., vol. 19, no. 1, pp. 97-104, 2016. doi: 10.31910/rudca.v19.n1.2016.114

[48] A. Arrieta, A. Taron, and L. Fuentes, "Evaluación de residuos de cadmio, cobre y plomo en cebollín, lechuga y repollo cosechados en Toledo Norte de Santander," Vitae, vol. 23, pp. 136-140, 2016. Available: https://search.proquest.com/openview/18b90d0feb702b9b19c7d86fc993df13/1.pdf?pqorigsite $=$ gscholar $\& \mathrm{cbl}=1806352$ 
[49] G. Echeverry, A. M. Zapata, M. I. Paéz, F. Méndez, and M. R. Peña, "Valoración del riesgo en salud para un grupo poblacional de la ciudad de Cali-Colombia por exposición a $\mathrm{Pb}, \mathrm{Cd}, \mathrm{Hg}, 2-4 \mathrm{D}$ y Diuron debido al consumo de agua potable y alimentos," Bioméd., vol. 35, no. 2, pp. 110-119, 2015. doi: 10.7705/biomedica.v35i0.2464

[50]Colombia, Ministerio de la Protección Social, Ministerio de Ambiente Vivienda y Desarrollo Territorial. Resolución 2115 de 2007. [Online]. Available: https://www.minambiente.gov.co/images/GestionIntegraldelRecursoHidrico/pdf/Legislaci \%C3 \%B 3n_del_agua/Resoluci \%C3\%B3n_2115.pdf

[51] N. Patiño Reyes and A. E. Bonilla Grande, "Determination of calcium, magnesium, lead and arsenic in sales and refined unrefined broken for human consumption in Bogota," Toxicol. Lett., vol. 196, p. S333, 2010. doi: 10.1016/j.toxlet.2010.03.1055

[52] G. A. Madero and N. J. Marrugo, "Detección de metales pesados en bovinos, en los valles de los ríos Sinú y San Jorge, departamento de Córdoba, Colombia," Rev. MVZ Córdoba, vol. 16, no. 1, pp. 23912401, 2011. doi: 10.21897/rmvz.298

[53] J. Bustamante, A. Chaparro, and M. Peláez, "Impacto de las actividades antrópicas derivadas de la industria petrolera en relación con la presencia de metales pesados en la ganadería bovina colombiana," Toxicol., vol. 32, no. 2, pp. 124-130, 2015. Available: http://rev.aetox.es/wp/wpcontent/uploads/hemeroteca/vol32-2/vol \%2032-2-127-130.pdf

[54] A. M. Gómez, F. V. Arevalo, and J. A. Lopez, "Intoxicación aguda con plomo en bovinos; reporte de caso," Acovez, vol. 24, no. 1, pp. 1-9, 2018. Available: https://www.produccionanimal.com.ar/suplementacion_mineral/23-intoxicacion_aguda_con_plomo.pdf

[55] M. J. Peláez Peláez, J. J. Bustamante-Caro, and E. D. Gómez-López, "Presencia de cadmio y plomo en suelos y su bioacumulacion en tejidos vegetales en especies de brachiaria en el Magdalena Medio Colombiano," Luna Azul, vol. 43, pp. 82-101, 2016. doi: 10.17151/luaz.2016.43.5

[56] A. Rodríguez Forero, J. F. González Mantilla, and R. Suárez Martínez, "Accumulation of lead, chromium, and cadmium in muscle of capitán (eremophilus mutisii), a catfish from the Bogota river basin," Arch. Environ. Contam. Toxicol., vol. 57, no. 2, pp. 359-365, 2009. doi: 10.1007/s00244-0089279-2

[57]F. Fuentes-Gandara, J. Pinedo-Hernández, J. Marrugo-Negrete, and S. Diéz, "Human health impacts of exposure to metals through extreme consumption of fish from the Colombian Caribbean Sea," Environ Geochem Health, vol. 40, no. 1, pp. 229-242, 2016. doi: 10.1007/s10653-016-9896-z

[58]P. E. Rodríguez Africano and E. J. Vergara Estupiñán, "Presencia de mercurio, plomo y cobre en tejidos de Orechromis niloticus: sector de la cuenca alta del Río Chicamocha, vereda Volcán, Paipa, Colombia," Prod. Más Limpia, vol. 10, no. 2, p. 114-26, 2016. doi: 10.22507/pml.v10n2a10

[59] S. E. Gallego Ríos, C. M. Ramírez Botero, B. E. López Marín, and C. M. Velásquez Rodríguez, "Evaluation of mercury, lead, and cadmium in the waste material of crevalle jack fish from the Gulf of Urabá, Colombian Caribbean, as a possible raw material in the production of sub-products," Environ. Monit. Assess, vol. 190, no. 3, p. 115, 2018. doi: 10.1007/s10661-018-6480-2

[60]E. A. López-Barrera and R. G. Barragán-Gonzalez, "Metals and metalloid in eight fish species consumed by citizens of Bogota D. C., Colombia, and potential risk to humans," J. Toxicol. Environ. Health, vol. Part A 79, no. 5, pp. 232-243, 2016. doi: 10.1080/15287394.2016.1149130

[61]D. F. Tirado, D. Acevedo, and P. M. Montero, "Caracterización del ñeque, bebida alcohólica elaborada artesanalmente en la Costa Caribe Colombiana," Inf. Tecnol., vol. 26, no. 5, pp. 81-86, 2015. doi: $10.4067 / \mathrm{s} 0718-07642015000500011$

[62] D. F. Tirado, K. J. Gonzalez Morelo, and D. Acevedo Correa, "Determinación de los niveles metanol, etanol y metales pesados en el ñeque elaborado en tres municipios de Sucre (Colombia)," Rev. Int. Contamin. Amb., vol. 33, pp. 135-141, 2017. doi: 10.20937/rica.2017.33.esp01.12

[63] S. E. Gallego Rios, C. M. Ramírez, B. M. López, S. M. Macías, J. Leal, and C. M. Velásquez, "Evaluation of mercury, lead, arsenic, and cadmium in some epecies of fish in the Atrato River Delta, 
Gulf of Urabá, Colombian Caribbean,” Water. Air. Soil Pollut., vol. 229, no. 8, pp. 11-48, 2018. doi: 10.1007/s11270-018-3933-8

[64] M. Jaime González, M. Landines, J. Borbón, M. Correal, C. Sánchez, and L. Rodríguez, "Evaluación de algunos marcadores de exposición a contaminantes en tres especies de bagres colombianos," Biota Colomb., vol. 15, no. 1, pp. 40-51, 2014. Available: http://revistas.humboldt.org.co/index.php/biota/article/view/341

[65] Organización de las Naciones Unidas para la Alimentación y la Agricultura (FAO), "Código de prácticas para la prevención y reducción de la presencia de plomo en los alimentos," 2004. [Online]. Available: www.fao.org/input/download/standards/10099/CXP_056s.pdf

[66] M. S. Sánchez, A. Bedoya, and R. Barahona, "Estudio preliminar de la fauna en el morro de basuras de Moravia y presencia de metales pesados en artrópodos y roedores," Univer. Scient., vol. 15, no. 1, pp. 49-58, 2010. doi: 10.11144/javeriana.sc15-1.psot

[67] M. S. Sánchez, A. Cogollo, C. Arroyave, R. D. Torrenegra, A. M. Giraldo, and R. Barahona, "Botanical diversity and heavy metal content in the residue matrix and plants at the Moravia dump in Medellín, Colombia diversidad," Rev. Fac. Nac. Agron., vol. 63, no. 1, pp. 5209-5224, 2010. Available: $\quad$ http://www.scielo.org.co/scielo.php?script=sci_arttext\&pid=S030428472010000100001\&lng=en\&tlng=en.

[68] A. Guerrero-Castilla, J. Olivero-Verbel, and J. Marrugo Negrete, "Heavy metals in wild house mice from coal-mining areas of Colombia and expression of genes related to oxidative stress, DNA damage and exposure to metals,” Mutat. Res. Genet. Toxicol. Environ. Mutagen., vol. 762, pp. 24-29, 2014. doi: 10.1016/j.mrgentox.2013.12.005

[69]E. Góngora, C. D. Cadena , and J. Dussán, “ Toxic metals and associated sporulated bacteria on Andean hummingbird feathers," Environ. Sci. Pollut. Res., vol. 23, no. 22, pp. 22968-22979, 2016. doi: 10.1007/s11356-016-7506-3

[70] J. Valdelamar-Villegas and J. Olivero-Verbel, "Bioecological aspects and heavy metal contamination of the mollusk Donax denticulatus in the Colombian Caribbean coastline," Bull. Environ. Contam. Toxicol., vol. 100, no. 2, pp. 243-239, 2018. doi 10.1007/s00128-017-2203-6

[71] J. Racero, J. Pinedo, J. Ballesteros, and J. Marrugo, "Metales pesados en especies de murciélagos (quiróptera) asociados a una finca bajo manejo silvopastoril en el departamento de Córdoba, Colombia," Acta Zoológ. Mex., vol. 33, no. 1, pp. 45-54, 2017. doi: 10.21829/azm.2017.3311012

[72] M. P. Escobar and J. Dussán, "Phytoremediation potencial of chromium and lead by Alnus acuminata subsp. acumunata," Environ. Prog. Sustain. Energy, vol. 35, no. 4, pp. 942-948, 2016. doi: 10.1002/ep. 12297

[73] Y. Naranjo-Sanchez and W. Troncoso-Olivo, "Contenidos de cadmio, cobre, zinc y plomo en órganos de rhizophora mangle de la ciénaga grande de Santa Marta, caribe colombiano," Bol. Investig. Mar. Cost., vol. 37, no. 2, pp. 107-129, 2008. doi: 10.25268/bimc.invemar.2008.37.2.194

[74] J. P. Parra and L. F. Espinosa, "Distribución de metales pesados ( $\mathrm{Pb}, \mathrm{Cd}$ y Zn) en perfiles de sedimento asociado a Rhizophora mangle en el río Sevilla-Ciénaga Grande de Santa Marta, Colombia," Bol. Investig. Mar. Cost., vol. 31, no. 1, pp. 95-110, 2008. doi: 10.25268/bimc.invemar.2008.37.1.184

[75]C. Cepeda, O. Rodríguez, C. Celis, and S. Forero, "Assessment of the phytoremediation potential of Lycianthes lycioides (L.) Hassl," Pharmacologyonline, vol. 3, pp. 27-31, 2017. Available: https://pharmacologyonline.silae.it/front/archives_2017_3

[76] O. Rodríguez, B. W. Andrade, L. F. Díaz, C. Celis, and A. Ortiz Ardila, "Quantification of heavy metals in lichens from the upper basin of the river Bogotá," Pharmacologyonline, pp. 21-27, 2016.https://pharmacologyonline.silae.it/files/archives/2016/vol2/PhOL_2016_2_A004_Rodriguez_ 21_27.pdf

[77] M. A. Ramírez Niño and M. A. Navarro Ramírez, "Heavy metal analysis on soils irrigated with water from the Guatiquía River," Cienc. Desarr., vol. 6, no. 2, pp. 167-175, 2015. doi: $10.19053 / 01217488.3787$ 
[78] J. Marrugo-Negrete, J. Pinedo-Hernández, and S. Díez, “Assessment of heavy metal pollution, spatial distribution and origin in agricultural soils along the Sinu River Basin, Colombia," Environ. Res., vol. 154, pp. 380-388, 2017. doi: 10.1016/j.envres.2017.01.021

[79] World Health Organisation, Health risks of heavy metals from long-range transboundary air pollution. Copenhagen, Denmark: WHO Regional Office for Europe, 2007.

[80] M. Romero-Barreiro, R. Pinilla-Castañeda, and C. A. Zafra Mejía, "Evaluación temporal de la concentración de metales pesados ( $\mathrm{Pb}$ y $\mathrm{Cu}$ ) asociada con el sedimento vial: Fontibón-Barrios unidos (Bogotá D. C., colombia). I 2015;19(2):315-33,” Ing. Univ., vol. 19, no. 2, pp. 315-333, 2015. doi: 10.11144/javeriana.iyu19-2.etcm

[81] C. A. Zafra Mejía, D. M. Santamaria Galindo, and C. D. Torres Galindo, "Análisis climático de la concentración de metales pesados asociados al sedimento depositado sobre vías urbanas," Rev. Salud Púb., vol. 17, no. 3, pp. 351-364, 2015. doi: 10.15446/rsap.v17n3.46672

[82] C. A. Zafra Mejia, E. C. Luengas Pinzon, and J. Temprano Gonzalez, "Influencia del tráfico en la acumulación de metales pesados sobre vías urbanas: Torrelavega (España)-Soacha (Colombia)," Rev.

Fac. Ing. Univ. Antioquia, no. 67, pp. 146-160, 2013. Available: https://revistas.udea.edu.co/index.php/ingenieria/article/view/16318

[83] J. M. Trujillo-González, M. A. Torres-Mora, S. Keesstra, E. C. Brevik, and R. Jiménez-Ballesta, "Heavy metal accumulation related to population density in road dust samples taken from urban sites under different land uses," Sci. Total Environ., vol. 553, pp. 636-642, 2016. doi: 10.1016/j.scitotenv.2016.02.101

[84] J. M. Trujillo-González and M. A. Torres-Mora, "Evaluación de metales pesados acumulados en polvo vial en tres sectores de la ciudad de villavicencio, Colombia," Luna Azul, no. 41, pp. 296-308, 2015. doi: 10.17151/luaz.2015.41.16

[85] Colombia, Ministerio de Ambiente Vivienda y Desarrollo Territorial, Resolución número 610. [Online]. Available: http://www.minambiente.gov.co/images/normativa/app/resoluciones/bfResoluci \%C3\%B3n \%20610\%20de \%202010\%20-\%20Calidad \%20del \%20Aire.pdf

[86] J. E. Pachón, "Análisis espacio-temporal de la concentración de metales pesados en la localidad de Puente Aranda de Bogotá-Colombia," Rev. Fac. Ing. Univ. Antioquia, no. 43, pp. 120-133, 2008. Available: $\quad$ http://www.scielo.org.co/scielo.php?script=sci_arttext\&pid=S012062302008000100011\&lng=en\&tlng=es.

[87] O. Ramírez, A. M. Sánchez de la Campa, F. Amato, R. A. Catacolí, N. Y. Rojas, and J. De la Rosa, "Chemical composition and source apportionment of PM10 at an urban background site in a highaltitude Latin American megacity (Bogota, Colombia)," Environ. Pollut., vol. 233, pp. 142-155, 2018. doi: 10.1016/j.envpol.2017.10.045

[88] A. M. Herrera Torres, C. A. Echeverry Londoño, G. J. Maya Vasco, and J. E. Ordoñez Molina, "Patologías respiratorias en niños preescolares y su relación con la concentración de contaminantes en el aire en la ciudad de Medellín (Colombia)," Rev. Ing. Univ. Medellín, vol. 10, no. 19, pp. 21-31, 2011. Available: https://revistas.udem.edu.co/index.php/ingenierias/article/view/435

[89] R. Rojano, H. Arregoces, and G. Restrepo, "Composición elemental y fuentes de origen de partículas respirables (PM10) y partículas suspendidas totales (PST) en el área urbana de la ciudad de Riohacha, Colombia," Inf. Tecnol., vol. 25, no. 6, pp. 3-12, 2014. doi: 10.4067/s0718-07642014000600002

[90] J. Fagundo Castillo and C. Doria Argumedo, "Niveles de metales en partículas atmosféricas en la zona minera de carbón, norte de Colombia," ITECKNE, vol. 14, no. 2, pp. 110-121, 2017. doi: 10.15332/iteckne.v14i2.1765

[91] N. E. Arias-Ortiz, G. Icaza-Noguera, and P. T. Ruiz-Rudolph, "Thyroid cancer incidence in women and proximity to industrial air pollution sources: A spatial analysis in a middle size city in Colombia," Atmos. Pollut. Res., no. 3, pp. 464-475, 2017. doi: 10.1016/j.apr.2017.11.003 
[92] M. Cobo, A. Gálvez, J. A. Conesa, and C. Montes de Correa, "Characterization of fly ash from a hazardous waste incinerator in Medellin, Colombia," J. Hazard. Mater., vol. 168, no. 2-3, pp. $1223-$ 1232, 2009. doi: 10.1016/j.jhazmat.2009.02.169

[93] A. E Fuentes and L. Y. Falla, "Evaluación y análisis de plomo presente en ambientes interiores a través de monitoreo personal en dos jardines infantiles de las respectivas localidades de Puente Aranda, Fontibón y Kennedy de Bogotá. D. C.," PhD Dissertation, Ing. Ambien. Sanitar. Univ. La Salle, Bogotá, Colombia, 2008.

[94] J. J. Feria, J. L. Marrugo, and H. González, "Heavy metals in Sinú river, department of Córdoba, Colombia, South America," Rev. Fac. Ing. Univ. Antioquia, no. 55, pp. 35-44, 2010. Available: https://revistas.udea.edu.co/index.php/ingenieria/article/view/14679

[95]L. Tejeda-Benitez, R. Flegal, K. Odigie, and J. Olivero-Verbel, "Pollution by metals and toxicity assessment using Caenorhabditis elegans in sediments from the Magdalena River, Colombia," Environ. Pollut., vol. 212, pp. 238-250, 2016. doi: 10.1016/j.envpol.2016.01.057

[96] J. D. Restrepo, E. Park, S. Aquino, and E. M. Latrubesse, "Coral reefs chronically exposed to river sediment plumes in the southwestern Caribbean: Rosario Islands, Colombia," Sci. Total Environ., vol. 553, pp. 316-329, 2016. doi: 10.1016/j.scitotenv.2016.02.140

[97] J. C. Arias Almeida and J. J. Ramírez Restrepo, "Caracterización preliminar de los sedimentos de un embalse tropical: caracterización represa La Fe (El Retiro, Antioquia, Colombia)," Limnetica, vol. 28, no. 1, pp. 65-78, 2009. Available: https://www.limnetica.com/es/caracterizaci \%C3\%B3npreliminar-de-los-sedimentos-de-un-embalse-tropical-represa-la-fe-el-retiro

[98] S. Burgos-Núñez, A. Navarro-Frómeta, J. Marrugo-Negrete, G. Enamorado-Montes, and I. UrangoCárdenas, "Polycyclic aromatic hydrocarbons and heavy metals in the Cispata Bay, Colombia: A marine tropical ecosystem," Mar. Pollut. Bull., vol. 120, no. 1-2, pp. 379-386, 2017. doi: 10.1016/j.marpolbul.2017.05.016

[99] A. F. Rúa Cardona, M. T. Flórez Molina, and J. P. Baena, "Variación espacial y temporal en los contenidos de mercurio, plomo, cromo y materia orgánica en sedimento del complejo de humedales de Ayapel, Córdoba, noroccidente colombiano," Rev. Fac. Ing., no. 69, pp. 244-255, 2013. Available: http://www.scielo.org.co/scielo.php?script=sci_arttext\&pid=S0120$62302013000400020 \& \operatorname{lng}=\mathrm{e} \&$ tlng=es.

[100] S. E. Romero Núñez, J. L. Marrugo Negrete, J. E. Arias Rios, H. R. Hadad, and M. A. Maine, " $\mathrm{Hg}, \mathrm{Cu}, \mathrm{Pb}, \mathrm{Cd}$, and $\mathrm{Zn}$ accumulation in macrophytes growing in tropical wetlands," Water Air Soil Pollut., vol. 216, no. 1-4, pp. 361-373, 2011. doi: 10.1007/s11270-010-0538-2

[101] P. P. Vallejo Toro, L. F. Vásquez Bedoya, I. D. Correa, G. R. Bernal Franco, J. AlcántaraCarrió, and J. A. Palacio Baena, "Impact of terrestrial mining and intensive agriculture in pollution of estuarine surface sediments: Spatial distribution of trace metals in the Gulf of Urabá, Colombia," Mar. Pollut. Bull., vol. 111, no. 1-2, pp. 311-320, 2016. doi: 10.1007/s11270-010-0538-2

[102] K. Caballero-Gallardo, A. Guerrero-Castilla, B. Johnson-Restrepo, J. de la Rosa, and J. Oliveiro-Verbel, "Chemical and toxicological characterization of sediments along a Colombian shoreline impacted by coal export terminals," Chemosphere, vol. 138, pp. 837-846, 2015. doi: 10.1016/j.chemosphere.2015.07.062

[103] C. A. Agudelo Calderón, J. C. García-Ubaqie, R. Robledo Martínez, C. A. García-Ubaque, and L. Quiroz Arcentales, "Evaluación de condiciones ambientales: aire, agua y suelos en áreas de actividad minera en Boyacá, Colombia," Rev. Salud Púb., vol. 18, no. 1, pp. 50-60, 2016. doi: 10.15446/rsap.v18n1.55384

[104] C. Macías Socha, M. García Colmenares, and S. P. Chaparro, "Determinación electroquímica de plomo y cadmio en aguas superficiales," Luna Azul, no. 44, pp. 27-38, 2017. doi: 10.17151/luaz.2017.44.3

[105] Colombia, Ministerio de Ambiente y Desarrollo Sostenible, Decreto 1076 de 2015. [Online]. Available: http://corponor.gov.co/ACTOSJURIDICOS/NORMATIVIDAD/decreto1076.pdf 